\title{
Pronunciation difficulties in the consonant system experienced by Arabic speakers when learning English after the age of puberty
}

Ana Marina do Val Barros

West Virginia University

Follow this and additional works at: https://researchrepository.wvu.edu/etd

\section{Recommended Citation}

Barros, Ana Marina do Val, "Pronunciation difficulties in the consonant system experienced by Arabic speakers when learning English after the age of puberty" (2003). Graduate Theses, Dissertations, and Problem Reports. 766.

https://researchrepository.wvu.edu/etd/766

This Thesis is protected by copyright and/or related rights. It has been brought to you by the The Research Repository @ WVU with permission from the rights-holder(s). You are free to use this Thesis in any way that is permitted by the copyright and related rights legislation that applies to your use. For other uses you must obtain permission from the rights-holder(s) directly, unless additional rights are indicated by a Creative Commons license in the record and/ or on the work itself. This Thesis has been accepted for inclusion in WVU Graduate Theses, Dissertations, and Problem Reports collection by an authorized administrator of The Research Repository @ WVU. For more information, please contact researchrepository@mail.wvu.edu. 


\section{PRONUNCIATION DIFFICULTIES IN THE CONSONANT SYSTEM EXPERIENCED BY ARABIC SPEAKERS WHEN LEARNING ENGLISH AFTER THE AGE OF PUBERTY}

Ana Marina do Val Barros

Thesis submitted to the
Eberly College of Arts and Sciences
at the West Virginia University
in partial fulfillment of the requirements for the degree
of

$$
\begin{gathered}
\text { Master of Arts } \\
\text { in } \\
\text { Foreign Languages }
\end{gathered}
$$

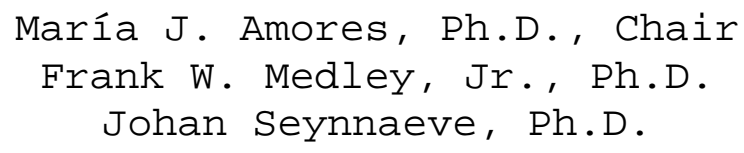

Keywords: Arabic speakers, Consonants, Pronunciation, Age 


\begin{abstract}
PRONUNCIATION DIFFICULTIES IN THE CONSONANT SYSTEM

EXPERIENCED BY ARABIC SPEAKERS WHEN LEARNING ENGLISH AFTER THE AGE OF PUBERTY

Ana Marina do Val Barros
\end{abstract}

The current study investigates the difficulties Arabic speakers may encounter when pronouncing English consonants. All participants are adults who have been in contact with the American culture for at least four years. The results show that the Arabic speakers in this study had difficulties to pronounce eight English consonants. The results also demonstrate that the difficulties experienced by Arabic speakers may differ depending on the country they come from. For instance, a person from Kuwait may experience different problems with English consonants when compared to a person from Egypt. This study provides insights and assists ESL teachers with the development of teaching strategies that will reduce or eliminate future problems regarding English consonants pronunciation by Arabic speakers. 


\section{Acknowledgements}

I would like to express my deepest appreciation to all of those who have greatly supported me during the process of this graduate program. With much gratitude, I acknowledge the members of my committee: Dr. Amores, for her advice and constant encouragement. Her confidence in me was a driving force to do my best; Dr. Medley, for all his helpful comments and suggestions; Dr. Seynnaeve, for the time and consideration he has always willingly and eagerly extended to me, especially during the phonetic transcriptions and data analysis; and Dr. Stjepanovic, although not an official member of the committee, was of extreme help, and made my defense possible.

I wish to extend my genuine appreciation to my special friends: Rashed, for all his support and words of advice; Flavia Costa, for her encouragement and time dedicated into helping me; and Susan, for her most helpful assistance. My sincere gratitude also goes to all the students, who were the subjects of this study, for their generous help in collecting the data.

Finally, I would like to express my special thanks to all the members of my family, especially my parents Dirce 
and Haroldo, for their great and true encouragement.

Without their love and support none of this would have been possible. 


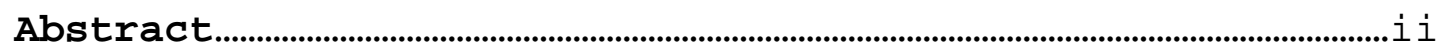

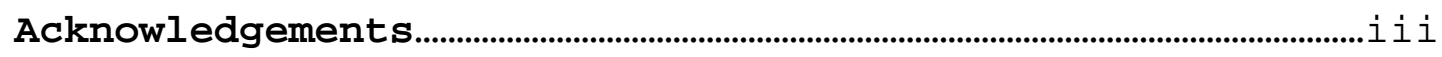

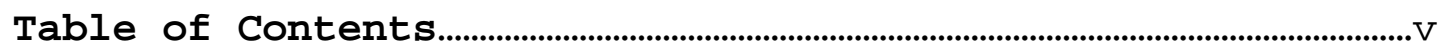

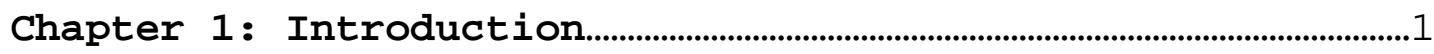

1.1 Statement of the Problem...................................................

1.2 Purpose of the Study .................................................................

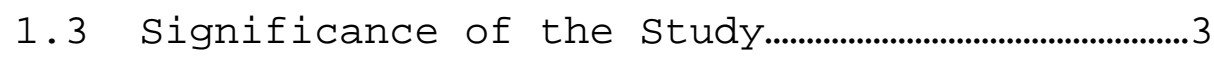

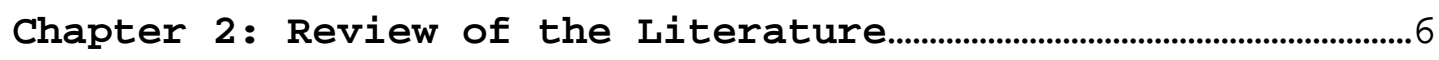

2.1 "The Brain Plasticity Theory" ........................................... 6

2.2 "The Critical Period Hypothesis".................................9

2.3 Studies Supporting a "Critical Period" for

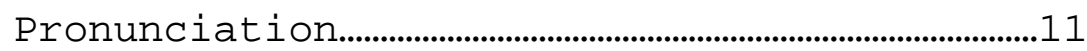

2.4 Studies that Argue Against a "Critical

Period" for Language Pronunciation

Acquis ition...................................................................................... 18

2.5 Influence of the Mother Tongue in

Pronunciation Acquisition...............................................2 2

2.6 Common Difficulties for Arabic Speakers.........25

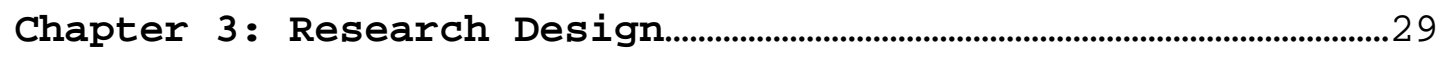

3.1 Participants...................................................................................29

3.2 Participants' Profile.........................................................30

3.3 Data Collection.............................................................................. 31 


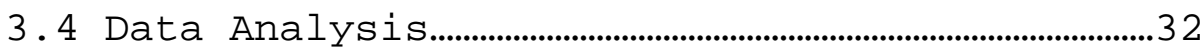

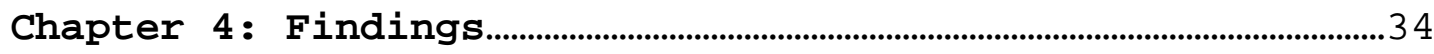

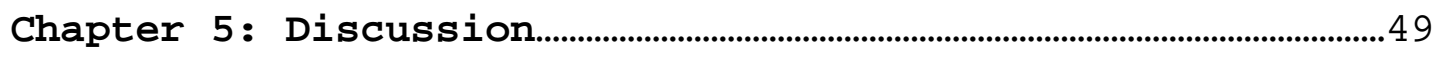

5.1 Standard American English and Standard Arabic

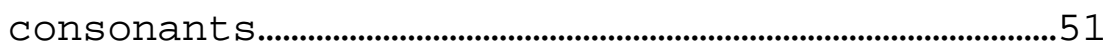

5.1.1 The Standard American English and Arabic Phonemic Inventory................................................................52

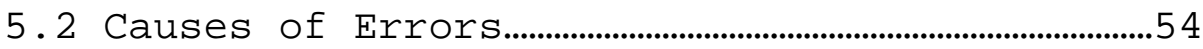

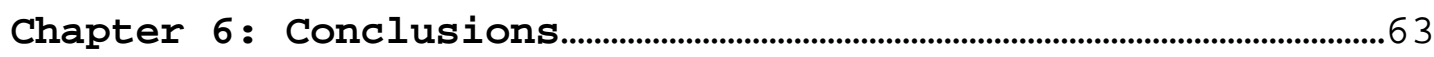

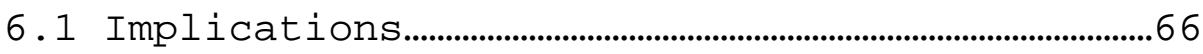

6.2 Limitations of the Study.....................................................67

6.3 Suggestions for Further Research.................................68

Works cited

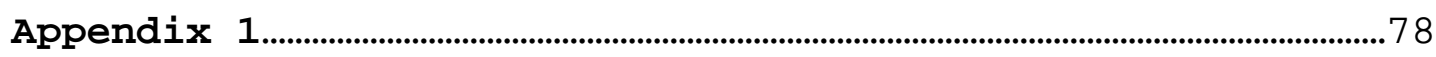

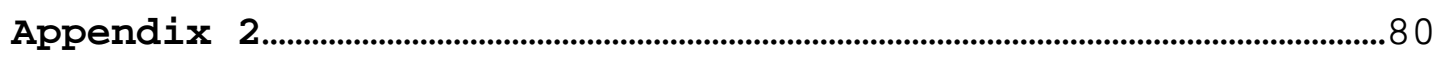




\section{Chapter 1}

\section{Introduction}

It seems to be a common desire among second-language learners to become indistinguishable from native speakers regarding pronunciation. However, this dream rarely turns into reality perhaps because pronunciation acquisition is far more complex than it may seem.

According to Wong (1987), cited by Murcia, Brinton and Goodwin (1996), pronunciation is not exclusively a linguistic matter. Factors such as age, exposure to target language, amount and type of prior pronunciation instruction, attitude towards the language, and the role of the learner's first language, need to be taken into consideration. As ESL teachers in the classroom, we find it difficult to control all the factors that interfere in pronunciation acquisition. However, understanding these factors will help us to determine the nature of the students' phonological performance and enable teachers to structure lessons that will improve pronunciation.

In this research paper I intend to focus on the English pronunciation of adult native speakers of Arabic and on the influence of the first language in the acquisition of the second language. A group of Arabic 
first language speakers, who were immersed in the target language environment after the age of puberty, were investigated in order to identify the patterns in their English speech as a consequence of the influence of their first language.

1.1 Statement of the Problem

Numerous studies suggest that after puberty it is very difficult to overcome pronunciation with a foreign accent (Asher \& Garcia, 1969; Oyama, 1976; Krashen, Long, \& Scarcella, 1980; Walsh \& Diller, 1981; Tahta, Wood, \& Loewnethal, 1981; Thompson, 1991; Towell \& Hawkins, 1992; Singleton \& Lengyel, 1995).

Arabic speakers learning English experience some difficulties with pronunciation, grammar, and vocabulary. In pronunciation, more specifically, there has been almost no research. The research conducted in this area to date often focuses on vowel pronunciation and seeks to identify problems of Arabic-speaking learners of English who never left their countries or who have been in an Englishspeaking country for a short period of time. I have no knowledge of literature, to date, which investigates pronunciation difficulties experienced by Arabic speakers who were immersed in an English-speaking country for a 
considerable period of time and who were very motivated to improve their pronunciation to the point of losing their foreign accent.

1.2 Purpose of the Study

The purpose of this study is to identify and analyze the difficulties experienced by Arabic speakers when pronouncing English consonants. The results will provide insights and assist teachers of English as a Second Language as they strive to reduce or eliminate future problems regarding pronunciation.

1.3 Significance of the Study

There have been a number of studies which investigated the grammar and vocabulary problems experienced by Arabic speakers learning English (Mukattash, 1981; Sayed, 1983; Meziani, 1984; Shaheen, 1984; Semmander, 1987; Radwan, 1988; Fakhri, 1994; Ali, 1995; Diab, 1996; Tushyeh, 1996). Other studies investigated pronunciation difficulties experienced by Arabic speaker learners of English. They focused mainly on vowel sounds pronunciation and investigated Arabs who never left their countries in order to learn English, or who were recently immersed in the 
English-speaking country (Australian Government, 1978; Kharma \& Hajjaj, 1989; Marzouk, 1993; Altaha, 1995).

The significance of the present study lies in the fact that it investigates Arabic speakers' difficulties with English consonant pronunciation. The participants have been in contact with the English language for a significant period of time, and this contact only began after the age of puberty. Furthermore, the participants in this study demonstrated high motivation to improve their English pronunciation. Results of this research may provide insights for ESL teachers with respect to the development and choice of instructional techniques that may improve the teaching of pronunciation of English consonant sounds to Arabic speakers.

The present chapter has provided a general introduction to this research project. Chapter 2 presents the review of the literature, which discusses pronunciation acquisition after the age of puberty, the influence of the mother tongue when learning a second language, and the common difficulties Arabic speakers encounter when learning English as second language. Chapter 3 presents the research design with a detailed description of the participants, as well as the procedures and methodology used for data collection. Chapter 4 presents the results obtained by the 
analysis of the interviews, from which eight consonants were identified to be of problematic pronunciation to Arabic speakers. Chapter 5 analyses the origin of the present problem by discussing the differences between the American English and Arabic consonant Inventories. The conclusion is presented in Chapter 6 . 


\section{Chapter 2}

Review of the Literature

It is very common to hear that to become a native-like speaker in a second language one has to be immersed in the language environment since childhood. Most of us know someone who started to learn a foreign language as an adult and, even after all the struggling, never managed to learn it properly, whereas their children learned it so well that they became indistinguishable from a native speaker. This chapter starts with the review of the existing literature on the implications for language acquisition after the age of puberty. Next, it discusses the influence of the mother tongue when acquiring a second language. Finally it will present the common difficulties Arabic speakers encounter when learning English as a second language.

In the following section theories attempting to explain the superiority of young learners are presented.

2.1 "The Brain Plasticity Theory"

The brain plasticity theory suggests that younger children find it easier to acquire language due to their cerebral receptivity. When compared to older children and adults, the younger children's brains have differences in 
functioning. The receptivity to language acquisition is related to organizational plasticity of the brain or to the lack of cortex specialization. With increasing age, the organization of the cortex becomes more specialized and language is lateralized in the left hemisphere of the brain, making it more difficult to acquire language.

Penfield and Roberts (1959) presented clinical evidence from physiological studies that supported the brain plasticity theory. Children and adults who had their left hemisphere of the brain injured in accidents were observed. Speech was lost, and after a certain period, only children regained the capability of speech. Moreover, from those children who recovered their speech, it was shown that the speech function somehow shifted from the left to the right hemisphere of the brain. Sodium amytal injected in the carotid artery, produced interference with the function of the right hemisphere, resulting in paralysis of one side of the body (hemiplegia) and a temporary loss of speech (aphasia) until the drug wore off. This experiment was done with the children who recovered their speech after the accident by developing the speech function in the right hemisphere of the brain. It was observed that the speech was temporarily gone as long as the drug had the effect of paralyzing the right hemisphere. The shift of functions 
from left to right hemisphere present only in children, strongly suggests the brain plasticity in children but not in adults. Based on this evidence, Penfield concluded that the critical period in terms of brain plasticity was closed near the age 10, and suggested that second language acquisition began before this age in order to develop better foreign language skills in the child. Lenneberg (1967), basing his research on the difference in the probability of recovery from acquired aphasia between children and adults, suggests a physiological age limitation for the first language acquisition related to the specialization of the cortex organization and to the lateralization of the speech function on the left hemisphere. Lenneberg infers that language learning can take place, at least in the right hemisphere, only between the ages of 2 and about 13 due to the presence of brain plasticity allowing the switch of the speech function from one hemisphere to the other. After puberty, those with well-established aphasia fail to overcome their language difficulties despite training, as do those who attempt to acquire a second language. 
2.2 "The Critical Period Hypothesis"

Lenneberg (1967) wrote a book called Biological

Foundations of Language where he named the belief in the superiority of young learners as the "Critical Period Hypothesis." This hypothesis claims that there is a biological or neurological period, which ends around the age of 12, beyond which it becomes extremely difficult to attain the complete mastery (grammar, pronunciation, syntax, etc...) of a second language. Lenneberg emphasizes the relationship between language acquisition and the progressive specialization of the cerebral hemispheres from birth until puberty. Singleton \& Lengyel (1995) agree about the relationship between language acquisition and the specialization of the cerebral hemispheres with the following statement:

During this period the dominant hemisphere becomes more and more specialized for language, and, at puberty, all language functions are concentrated in that part of the brain. This process of interhemispheric specialization, and the concomitant loss of cerebral plasticity, is held responsible for the alleged fact that after the onset of puberty languages have to be taught and 
learned through a conscious and laboured effort and that foreign accents cannot be overcome easily. (Singleton \& Lengyel, 1995, p.31).

Asher \& Garcia (1969) believe in the existence of an optimal period (before puberty) when language is acquired more easily. After this period, due to the change in the cellular plasticity, language acquisition becomes more difficult. However, according to the following quotation, it is not impossible:

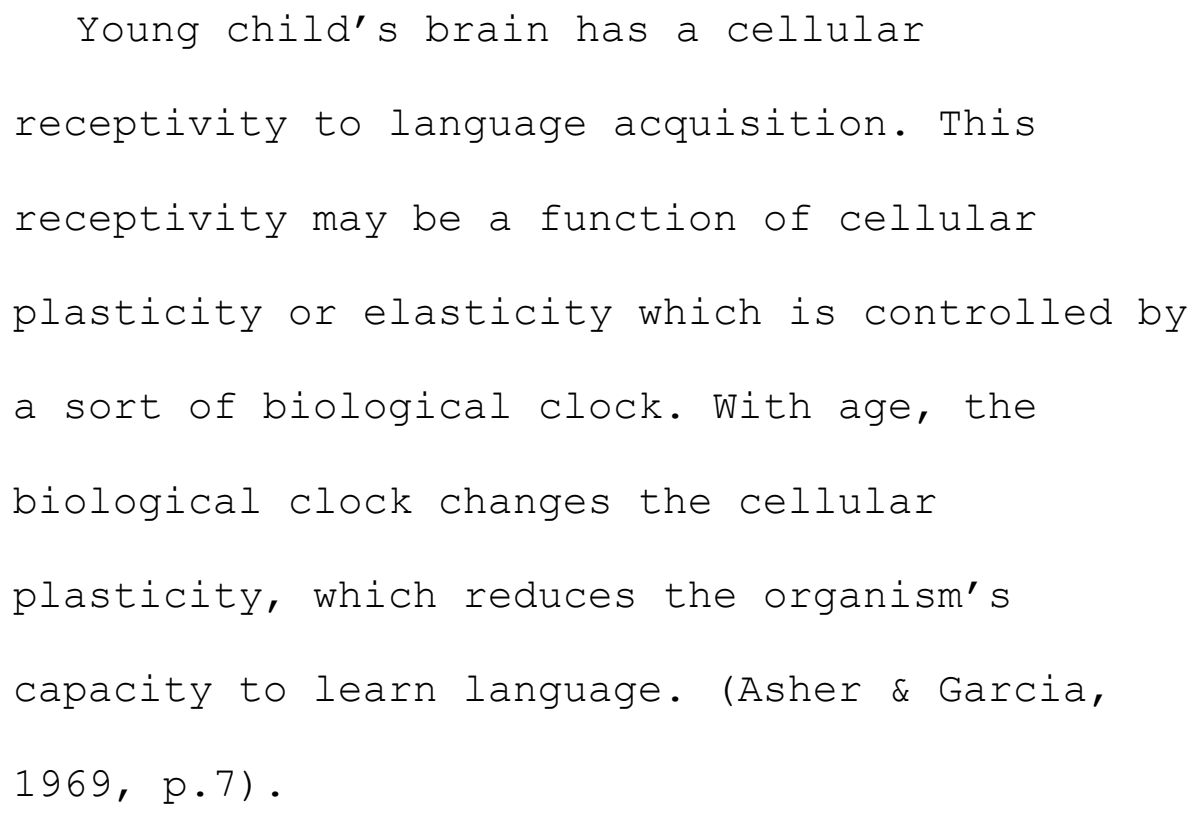


acquisition of each one of these components has not been specified.

\subsection{Studies supporting a "Critical Period" for} Pronunciation

According to Krashen, Long \& Scarcella (1980), available literature is consistent with three generalizations concerning the relationship between age and second language acquisition:

a) Adults proceed through early stages of syntactic and morphological development faster than children;

b) Older children acquire a second language faster than younger children;

c) Acquirers who begin natural exposure to second languages during childhood generally achieve higher second language proficiency than those beginning as adults. (Krashen, Long \& Scarcella, $1980, \mathrm{p} .573)$

Research conducted by Asher \& Garcia (1969), Oyama (1976), Krashen, Long \& Scarcella (1980), Walsh \& Diller (1981), Tahta, Wood \& Loewnethal (1981), Thompson (1991), Towell \& Hawkins (1992), Singleton \& Lengyel (1995), found evidence that challenges Lenneberg's hypothesis. 
In his hypothesis, Lenneberg (1967) does not specify whether there is a different critical period for different language skills (morphology, phonology, syntax), generalizing all language functions. However, if we take a closer look at the language acquisition process we may find not only one, but many "critical periods," one for each component of the language.

Fromkin, Krashen, Curtiss, Rigler, \& Rigler, (1998), report Genie's story, which is tragic, but it is a good example of language acquisition beyond the critical period. Genie was found in 1970 after being isolated in a small dark room for almost 14 years, which represented most of her life. At the time of her discovery Genie was an unsocialized, primitive, emotionally disturbed, uneducated child with no language whatsoever. The case of Genie is directly related to Lenneberg"s "critical period" hypothesis, since Genie was already a pubescent at the time of her discovery. From 1970 until 1979, Genie showed great progress in language acquisition and in cognitive skills, letting researchers become optimistic about the possibility of complete language acquisition. However, after 1979 Genie's progress in language development slowed dramatically whereas her cognitive skills continued to develop. According to the brain plasticity theory, after 
the age of puberty the brain loses its plasticity and the speech function is lateralized on the left hemisphere. Genie's case seems to support this theory. Due to the inadequate or absent language stimulation during the years before puberty, the development of the left hemisphere of her brain was inhibited. The disuse would have caused an atrophy of the language function of this hemisphere. At the age of 14, the closure of the brain plasticity supposedly had occurred and Genie's achievements in language acquisition depended on the other cortical areas and proceeded less efficiently due to previous specialization of these areas for other functions.

However, not everyone fully accepts the critical period hypothesis. According to Scovel (1981), there is no critical period for the acquisition of any aspect of language, except pronunciation. The pronunciation acquisition differs from the other aspects of the language performance because it is the only one which depends on physical reality. It has a neuromuscular basis. Learning words and the morphological and syntactic structures of language is a totally different process. He claims that the critical period for acquiring a native-like pronunciation in the second language closes around the age of 12, and those who start learning the second language after this 
period will never be able to acquire an accentless pronunciation.

Arabski (1984), points out that the acquisition of pronunciation in a second language is not only controlled by neurolinguistic processes but also by physical ones. As he says:

Second language and foreign language sounds and their combinations are produced by learners' speech organs. Involved in pronunciation are hundreds of muscles which produce about fourteen sounds a second. Their plasticity and efficiency directly influence the quality of speech produced. The muscles of speech organs undergo the same physiological processes as other human muscles. They are easier to shape in young individuals than in older ones, i.e., it is easier to learn new muscle movements when one is young and it is much harder to reshape them when one is old. In studying the speech of language learners it is difficult to decide to what extent their pronunciation is influenced by their neurolinguistic state of development and to what extent by the physical state of their speech organs. (Arabski, 1984, p.68) 
This theory tries to explain why children present less phonological transfer (influence of the mother tongue into the target language), if any, when learning a second language. Children's phonological muscles are easier to be shaped whereas adults will have more difficulty. Therefore, adults are more likely to present patterns in their speech not found in the speech of the native speaker. Towell \& Hawkins (1992), analyze the speech of adult English speakers learning French as a second language. They will have the tendency to pronounce words like fin as English "fan", or words like sud as English "sued", and French learning English would pronounce words like "fail" as "fell" and "this" as "zees". Spanish speakers learning English would have some difficulty with the vowel sounds. They would pronounce words like "meet" as "mit" or "seat" as "sit". This is clearly because they are transferring sounds from their native language to the second language. Their vocal muscles have already been shaped and the quality of the speech in a second language is affected. Seliger (1978) also believes in the existence of a critical period for pronunciation acquisition. He says that the ability to master a native accent in a second language is lost first and he situates that loss not much beyond the onset of puberty in most cases. 
Walsh \& Diller (1981), too, believe that there is a difference between learning the accent of a language and their other skills. They support the idea that overcoming a foreign accent after childhood is almost impossible. Their claim is based on the argument that "pronunciation is a lower-order process which is dependent on the early maturing and less adaptive macroneural circuits, while higher-order functions, such as grammar, are more dependent on the late maturing neural circuits"(p.12).

Oyama (1976) conducted a study with 60 Italian immigrants in the United States with the age of arrival ranging between 6 and 20. The results showed that the youngest arrivals produced near native to accentless speech, whereas those arriving after about age 12 did not, and substantial accents started appearing much earlier. Oyama also discussed several other studies of pronunciation acquisition among immigrants and his conclusion was that the results were consistent enough to support the theory of a critical period for pronunciation acquisition.

Tahta, Wood \& Loewenthal (1981) conducted another study on immigrants in Great Britain and the results showed that the speech of those starting at the age 6 was judged to be accentless. Between the age of 7 and 12 , the percentage of subjects accent-free decreased whereas the 
accent scores increased. All of the subjects who arrived after the age of 12 were judged to have a marked accent. Thompson (1991) also conducted a study on immigrants in the United States and concluded that "age on arrival was the best indicator of the accuracy of pronunciation in English" (p. 195). Those with the age of arrival before 10 had the best ratings.

Singleton \& Lengyel (1995), after comparing a number of studies done in this area, concluded that the attainment of a native accent is possible, but not guaranteed if one starts learning the language before puberty. The success of achieving a native-like pronunciation is more likely to happen if the exposure to the language begins before the age of 6 , and after this age the chances are progressively smaller. Thus, according to the studies mentioned so far, it would be extremely difficult to attain a native accent after puberty.

This suggests the existence of a critical period for second language pronunciation acquisition. However, some authors still claim that there is no "critical period" for any language components, not even for accent acquisition, and that the period should be called "optimal period" when it is more favorable for younger learners (and not impossible for older learners) to acquire a native accent. 
This would mark a new stage of research on age and second language acquisition, since, until now, the "critical period" for pronunciation acquisition has been the prevailing theory.

2.4 studies that argue against a "Critical Period" for Language Pronunciation Acquisition

Bialystok (1997) investigated a number of studies which indicated that older learners are capable of learning a second language in every aspect, and become indistinguishable from native speakers. Bongaerts, Planken, and Schils (1997) investigated Dutch learners of English and the results indicated that "late learners could achieve pronunciation levels indistinguishable from those of native speakers"(p.457). Ioup, Boustagui, Tigi, \& Moselle (1994) reported case-studies of complete mastery of second language learning that began after puberty. Juffs and Harrington (1995) investigated a group of Chinese ESL learners who began studying English in adulthood and became just as accurate as native speakers in every language aspect.

Kallkvist (1995) in a review of recent research on age-related differences in Second Language Acquisition, points out research done in order to demonstrate that 
learners exposed to the second language environment well after the closure of the hypothesized critical period can attain native-like proficiency. She reviews research conducted by Ioup et. al. (1994), in which a British woman, exposed to and immersed into the Egyptian culture at age 21, successfully acquired native-like spoken Arabic. Her performance was later judged by native speakers in the level of phonology, auditory perception and syntax. The results are reported in the following terms:

It was found that the subject consistently diverged from native speakers only when interpreting subject pronoun anaphora inside a relative clause a complex syntactic feature peculiar to Egyptian Arabic. This study has thus found an adult starter who was able to acquire even the phonology of a second language to the level of native speakers. (Kallkvist, 1995, p.157) .

Bialystok (1997), also believes it is possible for adults to develop a native-like pronunciation in a second language. However, she thinks it is important to examine the structural similarities between languages, as they can be a powerful predictor of success in language pedagogy. 
The following section discusses how the mother tongue can influence second language acquisition.

\subsection{Influence of the mother tongue in pronunciation} acquisition

So far, we have seen the divergence of opinions about the existence of a "critical period" for second language pronunciation acquisition. However, there is no doubt that languages are learned differently by children and adults, and that this is a direct result of the maturation of the brain. It is also true that some adults do achieve nativelike pronunciation, and that the degree of pronunciation accuracy varies considerably from individual to individual. Avery \& Ehrlich (1992) state that the fact that variability exists among adult learners means that ESL classroom time can profitably be devoted to improving students' pronunciation. In order to improve the students' pronunciation, first we have to identify the origin of the errors.

English speakers, most of the times, are able to identify Spanish accents, Arabic accents, German accents, French accents, etc. This shows that the sound pattern of the first language is being transferred into the second language. According to Avery \& Ehrlich (1992), the nature 
of a foreign accent can be determined by the learner's native language. Every language has its own particular inventory of phonemes, different rules of combining these phonemes into words, and different stress and intonation patterns. The mispronunciations of words by nonnative speakers are not random attempts to produce the correct sound, but they reflect the sounds, rules, stress, and intonation of their native language.

Avery \& Ehrlich (1992) point out that the sound system of the native language can influence the students' pronunciation of English in at least three ways:

1. When a learner encounters sounds in English that are not part of the sound inventory of the learner's native language. As mentioned before, the pronunciation of sounds depends on the proper use of the musculature in the mouth. Therefore, if the muscle needed for a certain sound is not exercised, the learner may not be able to produce it.

2. When the rules of combining sounds into words are different in the learner's mother tongue. Sometimes the sound present in the second language is also present in the native language, however, the rules of combining this sound into 
words may be different, causing a problem for the pronunciation of English.

3. The rhythm and melody of a language determine its patterns of stress and intonation. Learners may transfer the rhythm of their first language into English.

Students may also have a problem in hearing a sound that is not present in their native language inventory of phonemes. Avery \& Ehrlich (1992) believe that the native language affects the ability to produce English sounds as well as the ability to hear English sounds. Many ESL teachers may have experienced the frustration involved in having students continually repeat a mispronounced word in the same way. As Avery \& Ehrlich (1992) observe, "It is as if learners hear the second language through a 'filter', the filter being the sound system of the native language." $(\mathrm{p} \cdot \mathrm{XV})$

It may seem that the student does not want to correct him/herself, but actually, he/she hears the word through the sound system of the native language. Therefore, sounds that are familiar in the native language are heard instead of the actual sounds of English produced by the teacher. Murcia, Brinton \& Goodwin (1996) also believe in the existence of a filter when learning a second language. This 
theory, called the "contrastive analysis hypothesis," holds that second language acquisition is filtered through the first language, with the native language facilitating acquisition in those cases where the target structures are similar, and interfering with acquisition in cases where the target structures are dissimilar or nonexistent. Contrastive analysis can explain the reason for many language learning errors, but not all. Murcia, Brinton \& Goodwin (1996) said:

Today most researchers in the field, while minimizing the role that native language interference plays in other areas of language acquisition, would agree that interference (now more commonly referred to as negative transfer) is valid in second language pronunciation acquisition. Like Wado and Wardhaugh (1970), these researchers hold that negative transfer is a significant factor in accounting for foreign accent... (Murcia, Brinton \& Goodwin, 1996, p. 20). Marzouk (1993) agrees that the individual's past experience of his/her first language has a significant role in the process of learning a second language, especially if the second language is acquired after puberty. Adults will acquire the phonological system of a second language in a 
manner different from that of their first language, given that the acquisition of the new sounds in the second language must be integrated into already existing neural networks. (Murcia, Brinton \& Goodwin, 1996)

In summary, research reviewed herein suggests that the first language may be responsible for the patterns present in the accented pronunciation. ESL teachers, in order to provide efficient pronunciation instruction, should be aware of the types of difficulties students from different backgrounds are likely to face when learning English as a second language. A detailed study about every language is fundamental in order to find out the patterns brought from the native language into the target language. This way, ESL instructors will be able to design their teaching methodology according to each group's needs. This study investigates the pronunciation problems encountered by Arabic native speakers when learning English. While there might be other factors that influence pronunciation acquisition, this study focus on the influence of the mother tongue. 
2.6 Common difficulties for Arabic speakers learning English

There is very little research done regarding the difficulties that Arabic speakers face when learning English pronunciation.

Altaha(1995) shares this same opinion as he declared:

A great deal of research analyzing the grammatical, lexical and spelling errors committed by Arab students learning English has been conducted. However, the pronunciation errors made by Arab students in an EFL situation have not been dealt with. (Altaha, 1995, p. 110) Altaha's (1995) research is one of the few attempts to address this issue. He carried out a research study which investigated the problems Saudi Arabian students learning English faced when learning pronunciation. The participants in his study started learning English at age 13 and never left their native country to acquire English. Altaha collected the data by recording and analyzing the spoken English of the participants in different conditions and situations. His subjects have taken a number of English courses including writing, reading, conversation, grammar, and one phonetics course. Regarding consonants, his participants had problems with some pairs of consonant 
sounds (i.e. /t/ and /S/ as in "chair" and "share;" /V/ and /f/ as in "van" and "fan;" /p/ and /b/ as in "pat" and "bat"); consonant clusters (i.e. "grandfather" often mispronounced "grandifather"); consonant doubling (i.e. "allow" often mispronounced "al-low").

Kharma \& Hajjaj (1989) wrote a book attempting to identify problems Arab beginning learners of English face. They collected the data by oral interviewing their subjects. The mispronunciations were identified and then analyzed according to what they involve (consonants, vowels, stress). The authors identified some consonants (i.e. /p/, /v/, /g/, / $/ \mathrm{g}, / \partial /, / \mathrm{r} /, / \mathrm{l} /$ ) as problematic for Arabs to pronunce. However, considering the lack of literature in this area, they believe there is still much to be done.

The Australian Government (1978) published an article about the likely difficulties of English pronunciation Arabic speakers encounter when learning English. It was reported that Arabic speakers have difficulties with consonant clusters (pronouncing "espy" for "spy"), and

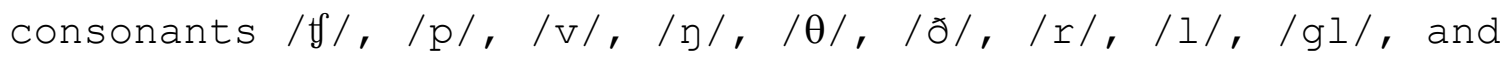
$/ d g /$. 
Marzouk (1993) carried out a study that investigated some aspects of phonological transfer from Arabic to English. His main focus was on vowel transfer and consonant clusters (two or more consonants together in a word). Marzouk analyzed a number of interlingual identifications of epenthesis (phonological intrusion: i.e. saying "filoor" instead of "floor") produced by Arabic learners in their oral production of English. Consonant transfer was not investigated.

Avery \& Ehrlich (1992) wrote a book about how to teach American English pronunciation to selected groups, and the difficulties listed, regarding English consonants, for Arabic speakers' pronunciation were: / / /, /ð/, /f/, /g/, $/ \mathrm{d} /, / \mathrm{r} /$, and consonant clusters. However, the difficulties listed were generalized to Arabic learners of all learning levels.

There is clearly a need for more research in this area. In Altaha's (1995) research Arabic speakers immersed in the target culture were not investigated. The study conducted by Kharma \& Hajjaj (1989) was limited to Arabs who were beginning learners of English. The article published by the Australian Government (1978) also concerned Arabs who were beginning learners of English. Difficulties experienced by Arabic speakers immersed in the 
target culture for a considerable period were not mentioned. Marzouk (1993), although conducting a research about phonological transfer, did not investigate consonant transfer. In the book written by Avery \& Ehrlich (1992) generalizes the difficulties to all learning levels. As we can see, there is a lack of research investigating pronunciation difficulties of Arabic speakers immersed in the target language culture for a considerable period of time.

Considering this factor, in my research study, I propose to investigate a group of post-puberty second language learners, from Arabic first language background, living in the United States for the minimal period of four years. The objective here is to point out patterns in their pronunciation that are related to their first language background. This study will be limited to the identification and analysis of consonants that are problematic for Arabic native speakers. 


\section{Chapter 3}

Research Design

The main objective of this study was to describe post puberty Arabic speakers' patterns in the pronunciation of English consonant sounds and to explore the origin of those patterns. The methodology employed to accomplish this purpose is explained below.

\subsection{Participants}

The Participants of this study were six Arabic native speakers, five males and one female, who came to the United States after the age of puberty and who have been living in this country for at least four years. Three of the participants are graduate students at West Virginia University, two from Egypt and one from Saudi Arabia. The other three are undergraduates at the same university and are all from Kuwait. They were selected according to the following requisites:

1. All participants must have been immersed in the English speaking country after the age of puberty 
2. All participants must have been living in the English speaking country for a minimum period of four years.

3. All participants must have a strong motivation to improve their pronunciation skills.

\subsection{Participants' profile}

All participants have been living in the United States for four years and demonstrated motivation to improve their English skills, especially pronunciation. They try to take advantage of every opportunity to do so. Although the participants have a constant interaction with native speakers of English, most of their friends are English nonnative speakers. Participant $A$ is the only female in this research study. She is from Egypt and is working on her Ph.D. in Computer Engineering. Participant B is a male from Egypt, who is working on his Ph.D. which also focuses on Computer Engineering. Participant $\mathrm{C}$ is a male from Saudi Arabia, who is working on his Ph.D. in Linguistics. Participant $D$ is a male from Kuwait, who is an undergraduate majoring in Civil Engineering. Participant E is a male from Kuwait, who is an undergraduate majoring in Journalism. Participant $F$ is a male from Kuwait, who is an undergraduate majoring in Mechanical Engineering. 


\subsection{Data Collection}

The participants of this study were individually approached by me and asked to participate in the research project by being interviewed and by reading some sentences and words in English. The choice of the interview was made in order to have a sample of their spontaneous conversation in English, thereby reducing the chances of them monitoring themselves while speaking. While spontaneous conversation would help me gather more accurate data since it would reduce monitoring, on the other hand, it allows them to avoid "problem" words. Therefore, I included the reading of sentences and isolated words to provide a more accurate data base. They were also asked to answer a questionnaire with questions about their background and past experiences (see Appendix 1). The participants were told that the project was designed to discover what problems regarding English consonants pronunciation Arabic speakers face. They were also told that the speech styles provided by them would be tape recorded.

The participants were allowed to ask questions about the research after my explanation was done, which were clearly answered. They were informed that their participation was voluntary and they would not receive any kind of compensation for taking part in the study other 
than the benefit from the opportunity to contribute to a research project on second Language Acquisition. Once all the explanation was over, the participants received a consent letter which contained information about the research and researcher. They signed two copies: one remained with them, and the other one with me.

The data were collected by first interviewing the participants. After the analysis of the interview, eight consonant phonemes were identified as problematic. Next a list of words containing the problematic sounds was created. These words were first integrated in sentences, and then arranged in a minimal pair list (see Appendix 2). The participants were asked to read the sentences and also the sets of minimal pairs. The subjects were asked to talk spontaneously as they were interviewed and for the sentences and words reading, the participants were asked to read them naturally. Some of the encounters were held at the participants' place of residence, others at my apartment or in a classroom at West Virginia University. Each encounter lasted between 15 and 20 minutes.

\subsection{Data Analysis}

The data were collected in the spring of 2003 . The interviews and readings were tape recorded for the purpose 
of analysis. The recordings were played back and two American English speakers were asked to identify the nonnative sounds as they occurred in the participants' speech. The judgments were performed by two American English native speakers, who were directed to pay special attention to the consonant sounds. The styles were written out and consonant sounds mispronounced in the speech styles were underlined and rewritten by the American English native speakers in the way they actually sounded (i.e. If the word "that" sounded like "dat", the judge would write a " $d$ " on the top of the "th" on the paper where the styles were transcribed). After that, I phonetically transcribed all words which contained consonants mispronounced by the participants

Each American English native speaker spent approximately four hours listening to the data. This time included pausing, rewinding, and replaying the tapes. Then, I compared the words underlined as nonnative by each one of the judges, and although there were a small number of slight differences, there was a high agreement between the two results. The following chapter presents the analysis of this data. 


\section{Chapter 4}

\section{Findings}

The objective of this study was to identify and analyze the pronunciation difficulties experienced by Arabic speakers with English consonant phonemes.

The consonant sounds with which at least four or five of the participants experienced problems, in order of difficulty were: /y/ at word final position as in "buying" [baylg], /l/ as in "civil" [sivil], /d/ in word final position as in "bed" [bed], /p/ as in "play" [pley], and/ð/ as in "risk" [ıIsk]. The consonant sound /v/ as in [fayv] represented a problem for only half of the participants, and the consonant sounds /d/, as in "job" [dab], and /ð/, as in "the" [ðə], were mispronounced by only participants $A$ and B.

Tables 1, 2, and 3 show that the participants had considerable difficulty in pronouncing correctly, according to SAE, five consonant sounds, and minor problems with three other sounds.

Consonant sounds are displayed in decreasing percentage of mispronunciation. The phonetic representation according to SAE and the phonetic representation according 
to the participants' speech are presented along with the percentage of error occurrence. The percentage of error reflects the number of errors that occurred for each participant in all possible occurrences of those phonemes. Consequently if a participant pronounced a particular problem consonant consistently wrong his/her percentage would be $100 \%$. If, on the other hand, he/she consistently pronounced the phoneme correctly, the percentage would be $0 \%$ 
Table 1: Results from the interview

\begin{tabular}{|c|c|c|c|c|}
\hline Participant & $\begin{array}{l}\text { Problematic } \\
\text { consonant }\end{array}$ & $\begin{array}{l}\text { Phonetic } \\
\text { representation } \\
\text { (SAE) }\end{array}$ & $\begin{array}{l}\text { Phonetic } \\
\text { representation } \\
\text { of } \\
\text { participants } \\
\text { mispronounced } \\
\text { speech }\end{array}$ & $\begin{array}{l}\frac{\circ}{\circ} \text { of } \\
\text { mispronunciation }\end{array}$ \\
\hline $\begin{array}{l}\text { A } \\
B \\
\text { C } \\
D \\
\text { E } \\
\text { F }\end{array}$ & $\begin{array}{l}\text { NG (in } \\
\text { phrase final } \\
\text { position) }\end{array}$ & $/ \mathrm{g} /$ & $/ \mathrm{nk} /$ & $\begin{array}{l}45.4 \\
20.0 \\
33.3 \\
45.5 \\
47.4 \\
56.3\end{array}$ \\
\hline $\begin{array}{l}\text { A } \\
B \\
C \\
D \\
E \\
F\end{array}$ & $\begin{array}{l}\text { L (in any } \\
\text { position) }\end{array}$ & $1+1 /$ & $/ 1 /$ & $\begin{array}{l}0 \\
75.0 \\
100 \\
80.0 \\
60.0 \\
14.3\end{array}$ \\
\hline $\begin{array}{l}\text { A } \\
B \\
\text { C } \\
D \\
\text { E } \\
\text { F }\end{array}$ & $\begin{array}{l}\text { D (in phrase } \\
\text { final } \\
\text { position) }\end{array}$ & $/ \mathrm{d} /$ & $/ \mathrm{t} /$ & $\begin{array}{l}28.5 \\
9.0 \\
10.0 \\
15.0 \\
5.5 \\
4.3\end{array}$ \\
\hline $\begin{array}{l}\text { A } \\
B \\
C \\
D \\
E \\
\text { E }\end{array}$ & $\begin{array}{l}\mathrm{P} \text { (in any } \\
\text { position) }\end{array}$ & $/ \mathrm{p} /$ & $/ \mathrm{b} /$ & $\begin{array}{l}11.1 \\
0 \\
73.3 \\
28.6 \\
54.5 \\
0\end{array}$ \\
\hline $\begin{array}{l}\text { A } \\
B \\
C \\
D \\
E \\
F\end{array}$ & $\begin{array}{l}\mathrm{R} \text { ( in any } \\
\text { position) }\end{array}$ & /小/ & $\mid r /$ & $\begin{array}{l}3.7 \\
7.1 \\
82.8 \\
36.4 \\
41.5 \\
1.7\end{array}$ \\
\hline $\begin{array}{l}\text { A } \\
B \\
C \\
D \\
\text { E } \\
\text { F }\end{array}$ & $\begin{array}{l}\mathrm{V} \text { (in any } \\
\text { position) }\end{array}$ & $/ \mathrm{v} /$ & $/ \mathrm{f} /$ & $\begin{array}{l}0 \\
0 \\
44 \cdot 4 \\
0 \\
0 \\
0\end{array}$ \\
\hline $\begin{array}{l}\text { A } \\
B \\
\text { C } \\
D \\
\text { E } \\
\text { F }\end{array}$ & $\begin{array}{l}\text { G (before } \\
\text { "e" and "i") } \\
\text { and J (in } \\
\text { any } \\
\text { position) }\end{array}$ & $/ d z /$ & $/ 3 /$ & $\begin{array}{l}40.0 \\
33.3 \\
0 \\
0 \\
0 \\
0\end{array}$ \\
\hline $\begin{array}{l}\text { A } \\
B \\
C \\
D \\
\text { D } \\
\text { F }\end{array}$ & $\begin{array}{l}\text { TH (in word } \\
\text { beginning } \\
\text { position) }\end{array}$ & /ð/ & $/ d /$ & $\begin{array}{l}100 \\
100 \\
0 \\
0 \\
0 \\
0\end{array}$ \\
\hline
\end{tabular}


Table 2: Results from the sentences reading

\begin{tabular}{|c|c|c|c|c|}
\hline Participant & $\begin{array}{l}\text { Problematic } \\
\text { consonant }\end{array}$ & $\begin{array}{l}\text { Phonetic } \\
\text { representation } \\
(\mathrm{SAE})\end{array}$ & $\begin{array}{l}\text { Phonetic } \\
\text { representation } \\
\text { of } \\
\text { participants } \\
\text { mispronounced } \\
\text { speech }\end{array}$ & $\begin{array}{l}\text { of } \\
\text { mispronunciation }\end{array}$ \\
\hline $\begin{array}{l}\text { A } \\
B \\
\text { C } \\
D \\
\text { E } \\
\text { F }\end{array}$ & $\begin{array}{l}\text { NG (in } \\
\text { phrase final } \\
\text { position) }\end{array}$ & $/$ / / & $/ \mathrm{k} /$ & $\begin{array}{l}42.9 \\
14.3 \\
71.4 \\
85.7 \\
42.9 \\
42.9\end{array}$ \\
\hline $\begin{array}{l}\text { A } \\
\text { B } \\
\text { C } \\
\text { D } \\
\text { E } \\
\text { F }\end{array}$ & $\begin{array}{l}\text { L (in any } \\
\text { position) }\end{array}$ & $1+1 /$ & $/ 1 /$ & $\begin{array}{l}0 \\
66.6 \\
66.6 \\
100 \\
33.3 \\
66.6\end{array}$ \\
\hline $\begin{array}{l}\text { A } \\
B \\
\text { C } \\
D \\
\text { E } \\
\text { F }\end{array}$ & $\begin{array}{l}\text { D (in phrase } \\
\text { final } \\
\text { position) }\end{array}$ & $/ d /$ & $/ \mathrm{t} /$ & $\begin{array}{l}25.0 \\
25.0 \\
0 \\
25.0 \\
50.0 \\
25.0\end{array}$ \\
\hline $\begin{array}{l}\text { A } \\
B \\
\text { C } \\
D \\
\text { E } \\
\text { F }\end{array}$ & $\begin{array}{l}\mathrm{P}(\text { in any } \\
\text { position) }\end{array}$ & $/ \mathrm{p} /$ & $/ \mathrm{b} /$ & $\begin{array}{l}22.2 \\
11.1 \\
0 \\
88.8 \\
66.6 \\
11.1\end{array}$ \\
\hline $\begin{array}{l}\text { A } \\
\text { B } \\
\text { C } \\
\text { D } \\
\text { E } \\
\text { F }\end{array}$ & $\begin{array}{l}\mathrm{R} \text { ( in any } \\
\text { position) }\end{array}$ & $/$ ๘/ & $|r|$ & $\begin{array}{l}0 \\
18.7 \\
56.3 \\
43.7 \\
43.7 \\
0\end{array}$ \\
\hline $\begin{array}{l}\text { A } \\
\text { B } \\
\text { C } \\
\text { D } \\
\text { E } \\
\text { F }\end{array}$ & $\begin{array}{l}\mathrm{V} \text { (in any } \\
\text { position) }\end{array}$ & $/ \mathrm{v} /$ & $/ \mathrm{f} /$ & $\begin{array}{l}0 \\
0 \\
25 \\
25 \\
25 \\
0\end{array}$ \\
\hline $\begin{array}{l}\text { A } \\
B \\
C \\
D \\
E \\
F\end{array}$ & $\begin{array}{l}\text { G (before } \\
\text { "e" and " } i \text { ") } \\
\text { and J (in } \\
\text { any } \\
\text { position) }\end{array}$ & $/ d \mathrm{~d} /$ & $/ 3 /$ & $\begin{array}{l}\text { Sound not } \\
\text { present in the } \\
\text { sentence } \\
\text { samples. }\end{array}$ \\
\hline $\begin{array}{l}\text { A } \\
B \\
C \\
D \\
E \\
F\end{array}$ & $\begin{array}{l}\text { TH (in word } \\
\text { beginning } \\
\text { position) }\end{array}$ & /ð / & $/ d /$ & $\begin{array}{l}100 \\
100 \\
0 \\
0 \\
0 \\
0\end{array}$ \\
\hline
\end{tabular}


Table 3: Results from the minimal pairs reading

\begin{tabular}{|c|c|c|c|c|}
\hline Participant & $\begin{array}{l}\text { Problematic } \\
\text { consonant }\end{array}$ & $\begin{array}{l}\text { Phonetic } \\
\text { representation } \\
(\mathrm{SAE})\end{array}$ & $\begin{array}{l}\text { Phonetic } \\
\text { representation } \\
\text { of } \\
\text { participants } \\
\text { mispronounced } \\
\text { speech }\end{array}$ & $\begin{array}{l}\text { o of } \\
\text { mispronunciation }\end{array}$ \\
\hline $\begin{array}{l}\text { A } \\
B \\
C \\
D \\
E \\
\text { E }\end{array}$ & $\begin{array}{l}\text { NG (in } \\
\text { phrase final } \\
\text { position) }\end{array}$ & $/ \mathrm{g} /$ & $/ \mathrm{k} /$ & $\begin{array}{l}100 \\
100 \\
100 \\
100 \\
100 \\
100\end{array}$ \\
\hline $\begin{array}{l}\text { A } \\
B \\
C \\
D \\
\text { E } \\
\text { F }\end{array}$ & $\begin{array}{l}\text { L (in any } \\
\text { position) }\end{array}$ & $1+1$ & $/ 1 /$ & $\begin{array}{l}\text { Sound not } \\
\text { present in } \\
\text { minimal pair } \\
\text { words }\end{array}$ \\
\hline $\begin{array}{l}\text { A } \\
B \\
\text { C } \\
D \\
\text { E } \\
\text { E }\end{array}$ & $\begin{array}{l}\text { D (in phrase } \\
\text { final } \\
\text { position) }\end{array}$ & $/ d /$ & $/ t /$ & $\begin{array}{l}0 \\
100 \\
0 \\
100 \\
100 \\
0\end{array}$ \\
\hline $\begin{array}{l}\text { A } \\
B \\
C \\
D \\
E \\
\text { E }\end{array}$ & $\begin{array}{l}\mathrm{P} \text { (in any } \\
\text { position) }\end{array}$ & $/ \mathrm{p} /$ & $/ \mathrm{b} /$ & $\begin{array}{l}0 \\
16.6 \\
0 \\
50.0 \\
66.6 \\
50.0\end{array}$ \\
\hline $\begin{array}{l}\text { A } \\
B \\
C \\
D \\
E \\
F\end{array}$ & $\begin{array}{l}\mathrm{R} \text { ( in any } \\
\text { position) }\end{array}$ & / d/ & $|r|$ & $\begin{array}{l}0 \\
0 \\
50.0 \\
50.0 \\
50.0 \\
0\end{array}$ \\
\hline $\begin{array}{l}A \\
B \\
C \\
D \\
E \\
F\end{array}$ & $\begin{array}{l}\mathrm{V} \text { (in any } \\
\text { position) }\end{array}$ & $/ \mathrm{v} /$ & $/ \mathrm{f} /$ & $\begin{array}{l}0 \\
0 \\
44 \cdot 4 \\
0 \\
0 \\
0\end{array}$ \\
\hline $\begin{array}{l}\text { A } \\
B \\
\text { C } \\
D \\
\text { E } \\
\text { F }\end{array}$ & $\begin{array}{l}\text { G (before } \\
\text { "e" and " } i ") \\
\text { and J (in } \\
\text { any } \\
\text { position) }\end{array}$ & $/ d z /$ & $/ 3 /$ & $\begin{array}{l}\text { Sound not } \\
\text { present in the } \\
\text { minimal pair } \\
\text { word. }\end{array}$ \\
\hline $\begin{array}{l}\text { A } \\
B \\
\text { C } \\
D \\
\text { E } \\
\text { F }\end{array}$ & $\begin{array}{l}\text { TH (in word } \\
\text { beginning } \\
\text { position) }\end{array}$ & /ð/ & $/ d /$ & $\begin{array}{l}\text { Sound not } \\
\text { present in } \\
\text { minimal pair } \\
\text { word. }\end{array}$ \\
\hline
\end{tabular}


As displayed in the tables, the consonant sound /y/ in phrase final position as in "buying" [bayig], was mispronounced as [baylgk]at least once by every participant in all speech styles. The percentage varied from 14.3\%, by participant $B$ in sentences reading, to $100 \%$ by all participants in the minimal pair ("mopping/mobbing") reading. Although this minimal pair was supposed to contrast "p" and "b", it was a good example of mispronunciation of the /y/ sound. The other consonant sounds, in order of difficulty, were/h/, as in "civil" [sivil], /d/ at word final position as in "bed" [bed], /p/ as in "play" [pley], /„/ as in "risk" [uIsk], and /V/ as in "five" [fayv], being mispronounced respectively as [sivil], [bet], [bley], [risk], and [fayf]. The /v/ consonant sound as in [fayv] did not represent a problem among all subjects. The only participant who mispronounced this sound in every speech style was participant C: $44.4 \%$ for minimal pairs and conversation styles, and 25\% for sentences reading style. Participants $\mathrm{D}$ and $\mathrm{E}$ only mispronounced it in the sentences reading style, with the percentage of occurrence of 25\% for both, and participants A, B, and F did not mispronounce it in any instance. The consonant sound /db/, as in "job" [dab], was only present in the 
interview style, and it represented a problem just for participants $A$ and $B$, who mispronounced it as [3ab]. The consonant sound /ð/, as in "the" [ðə], which was mispronounced as [də], likewise represented a problem for only participants $A$ and $B$ who consistently mispronounced it (100\% in every speech style).

As could be expected, the participants mispronounced the consonant sounds / $/ \mathrm{g}$ and /d/ mainly if the word in which the sound occurred was also phrase final. For example: if the words "doing well" were said without a pause between them, the participants had the tendency of pronouncing the /y/ sound correctly. However, if they paused, "doing (pause) well", the mispronunciation for /gk/ was more likely to occur. The same is true for the consonant sound /d/. If the participants said, for example, "studied English" without a pause between the two words, the right pronunciation of the /d/ was more likely to occur. The pronunciation of these words with pause, "studied (pause) English", would lead to a higher tendency of mispronunciation by devoicing the phoneme /d/ to a /t/ sound. Tables 4 and 5 show the percentage of mispronunciation when the words were linked to a following 
word, and the percentage of mispronunciation that occurred when there was a pause before the next word.

Table 4: Results from the interview

\begin{tabular}{|c|c|c|c|c|}
\hline Participants & $\begin{array}{l}\text { Consonant } \\
\text { sound }\end{array}$ & $\begin{array}{l}\text { o of } \\
\text { mispronunciation }\end{array}$ & $\begin{array}{l}\text { Consonant } \\
\text { sound }\end{array}$ & $\begin{array}{l}\text { o of } \\
\text { mispronunciation }\end{array}$ \\
\hline $\begin{array}{l}\text { A } \\
B \\
C \\
D \\
E \\
F\end{array}$ & $\begin{array}{l}\text { /n/ (in } \\
\text { word final } \\
\text { position } \\
\text { linked to } \\
\text { the next } \\
\text { word) }\end{array}$ & $\begin{array}{l}28.5 \\
33.3 \\
25.5 \\
0 \\
46.1 \\
16.6\end{array}$ & $\begin{array}{l}\text { /n/ (in } \\
\text { word final } \\
\text { position } \\
\text { with a } \\
\text { pause } \\
\text { before the } \\
\text { next word) }\end{array}$ & $\begin{array}{l}75 \cdot 0 \\
0 \\
50.0 \\
55.5 \\
50.0 \\
80.0\end{array}$ \\
\hline $\begin{array}{l}\text { A } \\
B \\
C \\
D \\
E \\
F\end{array}$ & $\begin{array}{l}\text { /d/ (in } \\
\text { word final } \\
\text { position } \\
\text { linked to } \\
\text { the next } \\
\text { word) }\end{array}$ & $\begin{array}{l}0 \\
0 \\
0 \\
11 \cdot 1 \\
0 \\
0\end{array}$ & $\begin{array}{l}\text { /d/ (in } \\
\text { word final } \\
\text { position } \\
\text { with a } \\
\text { pause } \\
\text { before the } \\
\text { next word) }\end{array}$ & $\begin{array}{l}66.6 \\
100 \\
25.0 \\
28.5 \\
50.0 \\
25.0\end{array}$ \\
\hline
\end{tabular}

Table 5: Results from the sentences reading

\begin{tabular}{|c|c|c|c|c|}
\hline Participants & $\begin{array}{l}\text { Consonant } \\
\text { sound }\end{array}$ & $\begin{array}{l}\text { \% of } \\
\text { mispronunciation }\end{array}$ & $\begin{array}{l}\text { Consonant } \\
\text { sound }\end{array}$ & $\begin{array}{l}\text { o of } \\
\text { mispronunciation }\end{array}$ \\
\hline A & $/ n /$ (in & 25.0 & $/ \mathrm{n} / \mathrm{in}$ & 66.6 \\
\hline B & word final & 20.0 & word final & 0 \\
\hline $\mathrm{C}$ & position & 50.0 & position & 80.0 \\
\hline $\mathrm{D}$ & linked to & 50.0 & with a & 80.0 \\
\hline $\mathrm{E}$ & the next & 20.0 & pause & 100 \\
\hline $\mathrm{F}$ & word) & 20.0 & $\begin{array}{l}\text { before the } \\
\text { next word) }\end{array}$ & 100 \\
\hline A & $/ d /$ (in & 0 & /d/ (in & 100 \\
\hline B & word final & 0 & word final & 100 \\
\hline $\mathrm{C}$ & position & 0 & position & 0 \\
\hline $\mathrm{D}$ & linked to & 0 & with a & 100 \\
\hline $\mathrm{E}$ & the next & 33.3 & pause & 100 \\
\hline $\mathrm{F}$ & word) & 0 & $\begin{array}{l}\text { before the } \\
\text { next word) }\end{array}$ & 100 \\
\hline
\end{tabular}

Table 6 shows the percentage of mispronunciation of the consonant sounds based on the total number of occurrences in all three speech styles. 
Table 6: Total results from all three speech styles

\begin{tabular}{|c|c|c|c|c|}
\hline Participant & $\begin{array}{l}\text { Problematic } \\
\text { consonant }\end{array}$ & $\begin{array}{l}\text { Phonetic } \\
\text { representation } \\
(\mathrm{SAE})\end{array}$ & $\begin{array}{l}\text { Phonetic } \\
\text { representation } \\
\text { of } \\
\text { participants } \\
\text { mispronounced } \\
\text { speech }\end{array}$ & $\begin{array}{l}\frac{\circ}{\circ} \text { of } \\
\text { mispronunciation }\end{array}$ \\
\hline $\begin{array}{l}\text { A } \\
\text { B } \\
\text { C } \\
\text { D } \\
\text { E } \\
\text { F }\end{array}$ & $\begin{array}{l}\text { NG (in } \\
\text { phrase final } \\
\text { position) }\end{array}$ & $/ \mathrm{g} /$ & $/ \mathrm{nk} /$ & $\begin{array}{l}62.7 \\
44.7 \\
63.4 \\
77.1 \\
63.4 \\
66.4\end{array}$ \\
\hline $\begin{array}{l}\text { A } \\
\text { B } \\
\text { C } \\
\text { D } \\
\text { E } \\
\text { F }\end{array}$ & $\begin{array}{l}\text { L (in any } \\
\text { position) }\end{array}$ & $/ 1 /$ & $/ 1 /$ & $\begin{array}{l}0 \\
70.8 \\
83.3 \\
90.0 \\
46.6 \\
40.4 \\
\end{array}$ \\
\hline $\begin{array}{l}\text { A } \\
\text { B } \\
\text { C } \\
\text { D } \\
\text { E } \\
\text { F }\end{array}$ & $\begin{array}{l}\text { D (in phrase } \\
\text { final } \\
\text { position) }\end{array}$ & $/ d /$ & $/ t /$ & $\begin{array}{l}17.8 \\
44.6 \\
3.3 \\
47.9 \\
55.0 \\
10.1\end{array}$ \\
\hline $\begin{array}{l}\text { A } \\
\text { B } \\
\text { C } \\
\text { D } \\
\text { E } \\
\text { F }\end{array}$ & $\begin{array}{l}\text { P (in any } \\
\text { position) }\end{array}$ & $/ \mathrm{p} /$ & $/ \mathrm{b} /$ & $\begin{array}{l}11.1 \\
9.2 \\
24.4 \\
40.8 \\
62.5 \\
20.3\end{array}$ \\
\hline $\begin{array}{l}\text { A } \\
B \\
\text { C } \\
\text { D } \\
\text { E } \\
\text { F }\end{array}$ & $\begin{array}{l}\mathrm{R} \text { ( in any } \\
\text { position) }\end{array}$ & / ๘/ & $|r|$ & $\begin{array}{l}1.2 \\
8.6 \\
63.0 \\
43.3 \\
45.0 \\
0.56 \\
\end{array}$ \\
\hline $\begin{array}{l}\text { A } \\
\text { B } \\
\text { C } \\
\text { D } \\
\text { E } \\
\text { F }\end{array}$ & $\begin{array}{l}\mathrm{V} \text { (in any } \\
\text { position) }\end{array}$ & $/ \mathrm{v} /$ & $/ \mathrm{f} /$ & $\begin{array}{l}0 \\
0 \\
23.1 \\
8.3 \\
8.3 \\
0\end{array}$ \\
\hline $\begin{array}{l}\text { A } \\
B \\
C \\
D \\
E \\
F\end{array}$ & $\begin{array}{l}\text { TH (in word } \\
\text { beginning } \\
\text { position) }\end{array}$ & /ð/ & $/ d /$ & $\begin{array}{l}100 \\
100 \\
0 \\
0 \\
0 \\
0 \\
\end{array}$ \\
\hline
\end{tabular}

As we can see from the table, after combining all

three speech styles to obtain the total percentage of mispronunciation of the consonant sounds, the /y/phoneme 
represented the highest percentage of errors among all participants. It was mispronounced $77.1 \%$ of the times it occurred by participant D and $44.7 \%$ by participant B. Every participant had a significant percentage of errors when producing this sound. The phoneme /v/ represented a very small problem for the participants of this study. Participants A, B, and F did not mispronounce it in any instance, and participants $\mathrm{D}$ and $\mathrm{E}$ had a very low percentage of errors (8.3\%). Participant C mispronounced it 23.1\% of the times. The phoneme///represented a problem for only participants A and B who consistently mispronounced it every time it occurred.

A further display of the results is shown in Figure 1, which is a bar graph showing the percentage of mispronunciation for each participant's speech. 
Figure 1: Percentage of errors for problematic consonant sound

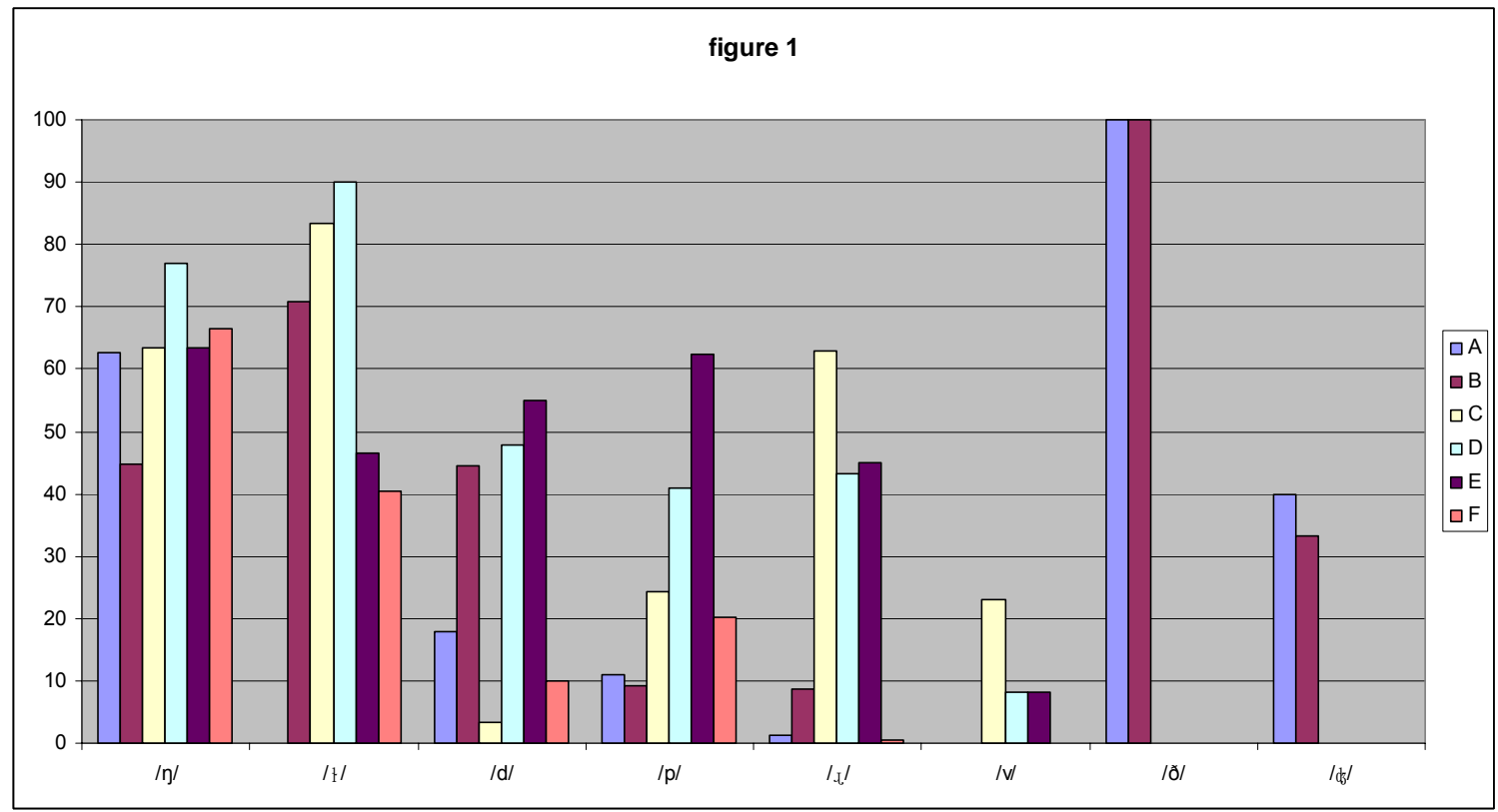

As we can see from figure 1, Participant A experienced difficulties with consonant sounds / g/, /d/, /p/, / J/, /dz/, and /ð/. Participant B experienced difficulties with

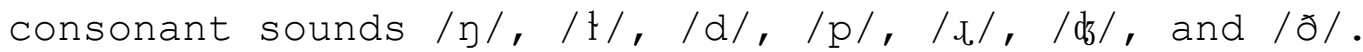
Participant $\mathrm{C}$ experienced difficulties with consonant sounds /p/, / t/, /d/, /p/, / l/, and /v/. Participant D experienced difficulties with consonant sounds / / / / / /, /d/, /p/, /ı/, and /v/. Participant E experienced difficulties with consonant sounds/g/, / / / /d/, /p/, / /, and /v/. Participant F experienced difficulties with

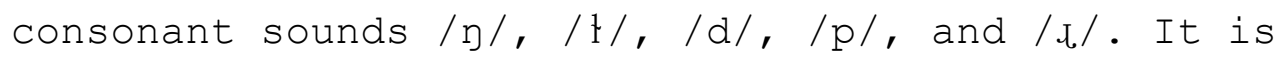
important to point out that participants $A$ and $B$ are the only Egyptians in this study, and they were the only 
subjects to present difficulties pronouncing the phonemes /dz/ and /ð/.

Given the percentage of each mispronounced consonant sound in each participant's speech, an average was calculated for each mispronounced consonant sound from all participants' speech

Figure 2 is a bar graph representing the average of each mispronounced consonant sound considering all participants as a whole.

Figure 2: results of the average of each mispronounced consonant sound

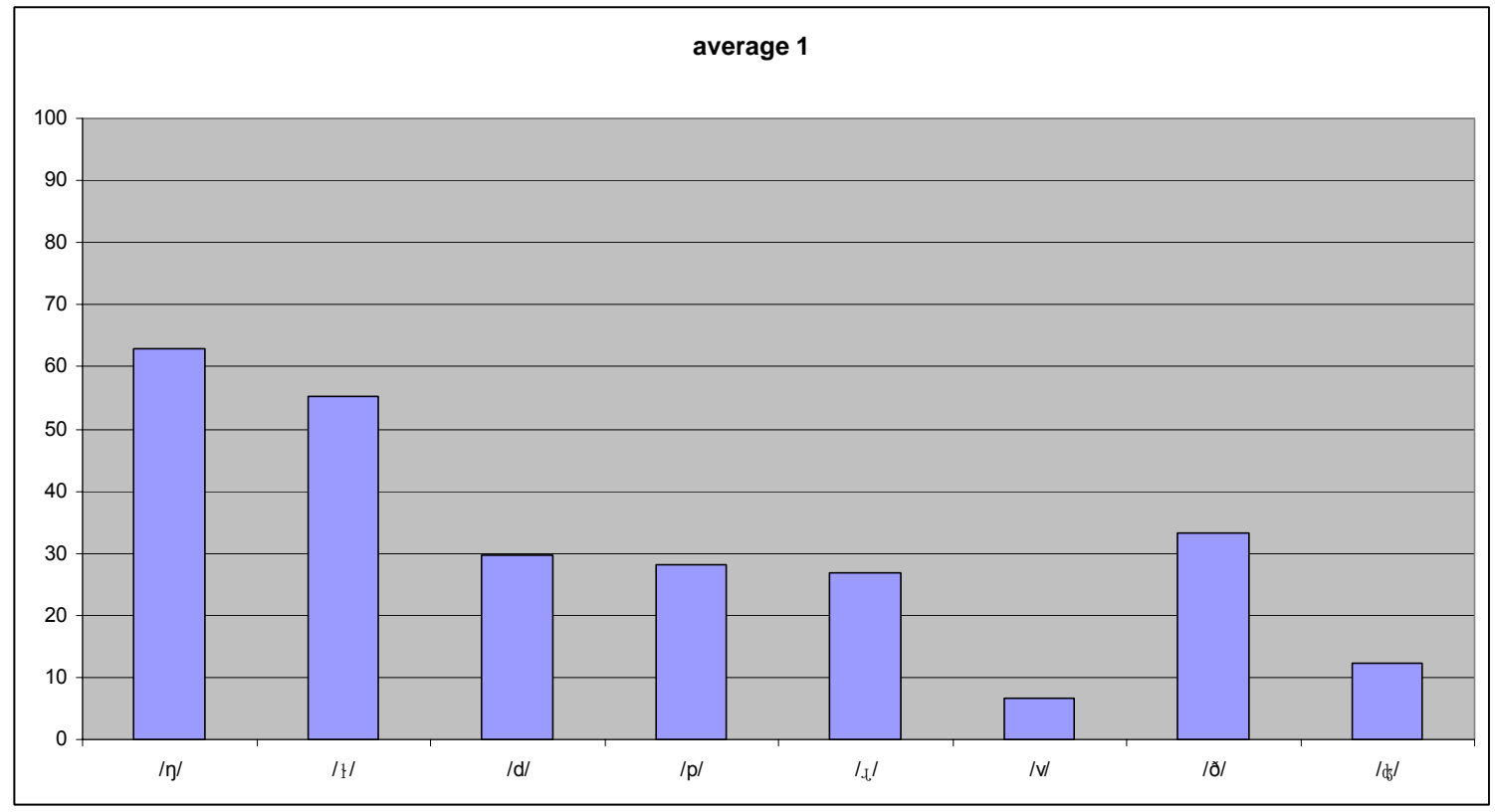

As we can see from figure 2, the consonant sounds /y/ and /1/ represent the highest percentages of errors in the Arabic speakers' speech, they were respectively 
mispronounced 63\% and 56\% of the total amount of times it occurred, and /v/ represents the lowest percentage of errors, as it was mispronounced only $6.6 \%$ of the total amount of times it occurred. The consonant sounds /d/, /p/, and /./ represent significant percentages of pronunciation errors too. The percentages of mispronunciation for each of these phonemes were respectively $30 \%$, 28\%, and $27 \%$. The consonant sound /ð/ also represents a considerable percentage of errors as it shows 33\% of mispronunciation from the total amount of times it has occurred. However, the mispronunciation of this sound, as well as the consonant sounds /dy/ and /v/, was not a common error among participants, therefore it cannot be considered a pattern in all Arabic speakers' pronunciation. A graph representing only the consonant sounds that are mispronounced by at least four or five of the participants would provide us with a better understanding of the patterns of mispronunciation in the Arabic speakers' speech. Figure 3 is a bar graph which represents only the consonant sounds that are mispronounced by at least four or five participants 
Figure 3: results of the average of each mispronounced consonant sound present in at least four or five participants' speech.

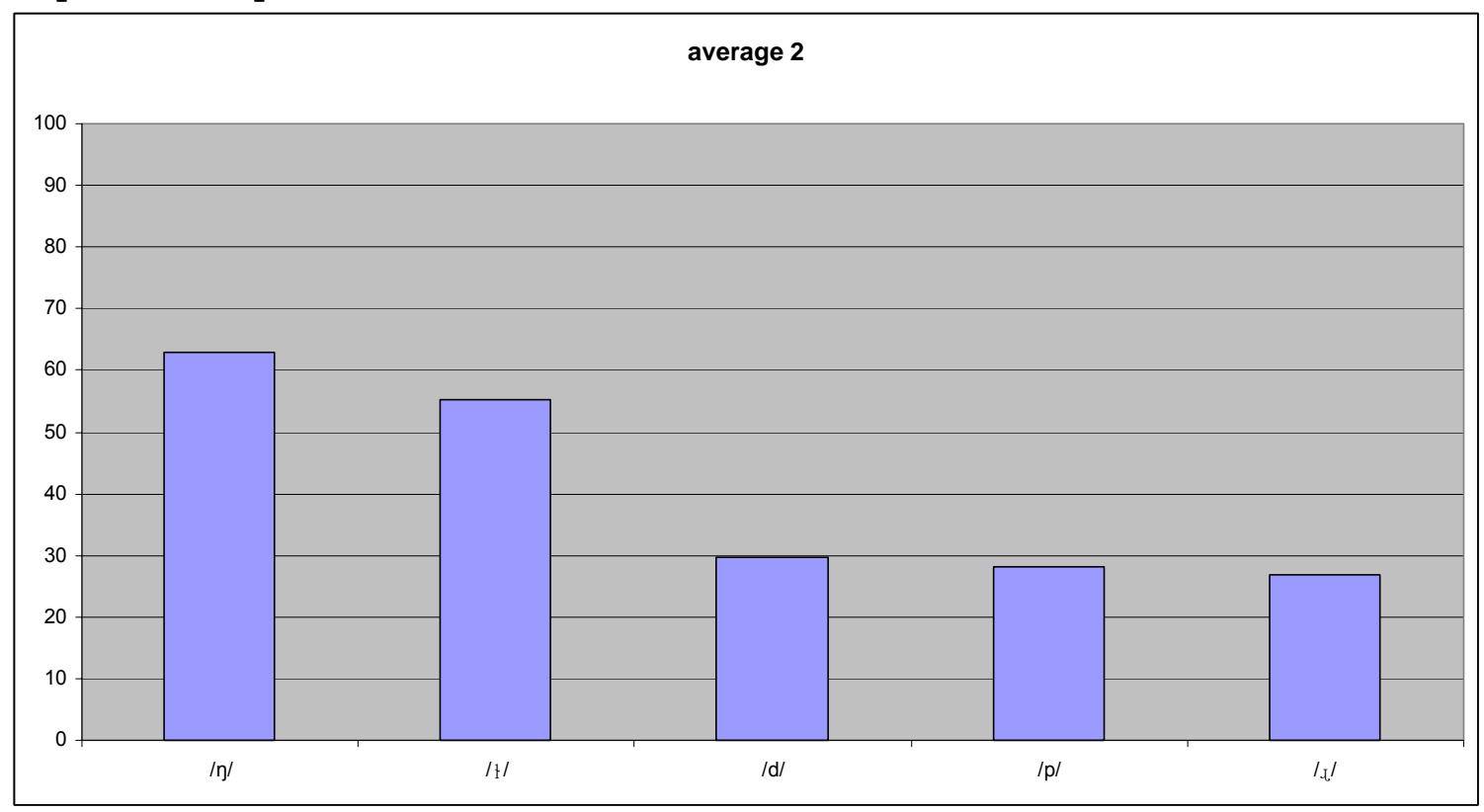

Figure 3 represents the common difficulties for Arabic speakers when pronouncing consonant sounds since it shows the average of errors encountered in at least four or five participants' speech. Based on this graph, the consonant sound /y/ is the most commonly mispronounced by Arabic speakers as it was mispronounced 63\% of the total number of occurrence, and consonant sound / d/ is the least mispronounced of these five consonants, however still with a significant percentage of occurrences of $27 \%$.

After having the problematic consonants identified, the next chapter will look at the differences and similarities between the Standard Arabic and American English consonant phonemic inventories, in order to find 
the origin of the mispronunciations produced by the participants of this study. 


\section{Chapter 5}

Discussion

One of the participants in this research reported an interesting episode that happened to him, which is a good example of the importance of accurate pronunciation of consonants by nonnative speakers. He was driving his car downtown looking for a place to park. He saw a police officer and asked if it was okay to park his car on a certain place. "Can I [bark] here?," he asked, and the police officer said yes. The participant gladly parked his car on that spot. When he returned he found a parking ticket on his window. He did not understand the reason for that and went after the police officer. "You said I could [bark] here." And the officer replied "you can bark anywhere, but you cannot park here."

Kharma \& Hajjaj (1989) believe that when learning a second language, it is very important to become familiar with its consonant system. If the learners encounter problems in producing the correct phonetic realization of a consonant phoneme, it may result in misunderstandings in oral communication. An incorrect realization of a phoneme in a whole sentence may lead to a totally different 
understanding by the listener, as illustrated by the anecdote at the beginning of this chapter.

Other mispronunciations of consonant phonemes may not result in misunderstanding, but it may be identified as a foreign accent. In my study there was a common desire among the participants to become indistinguishable from native speakers. For this reason it is important to identify the difficulties in the pronunciation of the target language experienced by nonnative speakers in order to help them overcome their foreign accent.

The objective of this study was to identify and analyze difficulties in the pronunciation of English consonant sounds experienced by Arabic native speakers who have been immersed in the target language culture for at least four years. The speech problems encountered in this study differ from previous studies conducted by Kharma \& Hajjaj (1989), Avery \& Ehrlich (1992), Altaha (1995), and Tushyeh (1996) in significant ways. These researchers dealt with Arabic speakers who arrived recently from their native countries or who never left their country in order to learn a second language. As a consequence, the participants of these studies did not have the experience of living in the country where the target language is spoken. Therefore, as could be expected, more consonants were identified as 
problematic (/t/, /p/, /v/, /g/, / / /, /ð/, /r/, /l/, /gl/, and $/ \mathrm{d} / /$.

In the present study, the participants were already in contact with the American English native accent for a significant period of time and were also very motivated to lose their nonnative pronunciation. Therefore, less mistakes regarding consonant pronunciation occurred if compared to groups of Arabic speakers recently living in an English-speaking country or who never left their country in order to learn a second language.

This research dealt with difficulties experienced by Arabic speakers in producing eight specific English consonant sounds. To provide a context for the findings of the study, the next section presents a description and discussion of Standard American English and Standard Arabic consonants.

5.1 Standard American English and Standard Arabic consonants

Many researchers believe (e.g. Broselow, 1988) that differences between the native language and the target language may be used to explain the occurrence of errors in the acquisition of a second language. Especially interference, which is the negative influence of the mother 
tongue (L1) on the performance of the target language (L2), is a well known factor responsible for learners' errors. Therefore, a brief discussion of the consonant system in both L1 and L2 is very important in order to understand the origin of these errors.

5.1.1 The Standard American English and Arabic Phonemic Inventory

The great majority of the symbols of the International Phonetic Alphabet (IPA) used in the inventory of English phonemes are familiar, since they come from the Roman alphabet. A phonetic representation of the sounds is very important, since it has one symbol for each sound, thus, we are able to transcribe the sounds of the language more accurately. A phonetic representation is fundamental especially in English, since the language allows one letter to have different sounds on different occasions. For example, the letter "c" has three different pronunciations in the words "ocean", "cast", and "ceiling". The following tables show the full inventory of SAE consonant phonemes and the Standard Arabic consonants inventory. 
Phonemic Inventory of Consonants in American English

\begin{tabular}{|c|c|c|c|c|c|c|c|c|c|}
\hline & bilabial & labiodental & dental & alveolar & alveopalatal & retroflex & palatal & velar & glottal \\
\hline plosive & $\mathrm{p} \quad \mathrm{b}$ & & & $\mathrm{t} \quad \mathrm{d}$ & & & & $\mathrm{k} g$ & \\
\hline fricative & & f $v$ & $\theta \quad$ ठ & $\mathrm{s} \quad \mathrm{Z}$ & $\int 3$ & & & & $\mathrm{~h}$ \\
\hline affricate & & & & & $t \int d 3$ & & & & \\
\hline nasal & $\mathrm{m}$ & & & $\mathrm{n}$ & & & & y & \\
\hline liquid & & & & $1 t$ & & & & & \\
\hline glide & W & & & & & & $\mathrm{j}$ & & \\
\hline
\end{tabular}

Phonemic Inventory of Consonants in Classical Arabic

\begin{tabular}{|c|c|c|c|c|c|c|c|c|c|}
\hline & bilabial & labiodental & dental & alveolar & alveopalatal & palatal & velar & pharyngeal & glottal \\
\hline plosive & $\mathrm{b}$ & & $\mathrm{t} d$ & & & & $\mathrm{k} \quad \mathrm{g}$ & & $?$ \\
\hline fricative & & $\mathrm{f}$ & $\theta$ ठ & $\mathrm{s} \quad \mathrm{z}$ & $\int$ & & & $\hbar S$ & $\mathrm{~h}$ \\
\hline affricate & & & & & $d 3$ & & $x \quad \gamma$ & & \\
\hline nasal & $\mathrm{m}$ & & $\mathrm{n}$ & & & & & & \\
\hline liquid & & & & $1 \mathrm{r}$ & & & & & \\
\hline glide & w & & & & & $\mathrm{j}$ & & & \\
\hline emphatic & & & $t^{f} d^{\varsigma}$ & $s^{\varsigma} z^{\uparrow} l^{\uparrow}$ & & & & & \\
\hline
\end{tabular}


As we can see from the tables, Arabic has twentynine consonants, whereas English has twenty-four. Most of the consonants are found in both languages, however, some of them are found in one language but not in the other. This situation may cause pronunciation problems for Arabic speakers, especially with those sounds which are absent in the Standard Arabic Alphabet. By identifying the participants' consonant sound mispronunciations and then looking at the English Phonemic Inventory and the Arabic Phonemic Inventory, we may be able to explain the origin of such errors.

Comparing the Arabic and English inventories we can see that Arabic has emphatic consonants, and two of the English consonants, /p/ and /v/, are not present in the standard Arabic inventory of phonemes. Other consonants (i.e. /n/, /r/, /d/) although present in both inventories, may have a different phonetic realization (i.e. while Arabic /r/ is an alveolar trill, the English /r/ is a frictionless retroflex continuant).

\subsection{Causes of Errors}

As mentioned before, while some of the English consonant sounds are not present in the Standard Arabic 
inventory of phonemes (see tables A and B), others are present. However, they have a different phonetic realization. According to Tushyeh (1996), some of the pronunciation problems may be attributed to the learners' misconception that English consonant sounds have equivalents in Arabic. This misconception leads them to substitute the assumed similar Arabic consonant sounds for English ones. The failure to realize that English consonant phonemes have a particular phonetic realization can be the cause of the foreign pronunciation accent. As she says:

The [...] major cause of errors is interlingual, i.e. interference from the first language of the learner. [...]

Language transfer from the first language is a significant factor in second language learning. Richards (1971) found that 36\% of errors can be attributed to the first language... (Tushyeh, 1996 p.110)

From all the consonant sounds mispronounced by our participants, only two are from phonemes not present in Arabic, /p/ and /v/, and for this reason, they are likely to cause trouble. As we can see in table B (p.53), Arabic does not have the voiceless bilabial stop /p/, but the 
voiced counterpart /b/ is present in the phoneme inventory. An article published by the Australian Government (1978) says that the phoneme /p/ may sometimes occur in loan words in Arabic, such as "Poland," however, the /p/ will be always replaced by its voiced counterpart /b/ (i.e. Bulanda = Poland). Even where Arabic speakers give the more learned pronunciations of foreign words and names with "p", they are likely to have trouble hearing the difference between $/ \mathrm{p} /$ and $/ \mathrm{b} /$.

All participants in this study, at some point, experienced problems with the phoneme /p/. Words such as "park," "pin," "pack," and "peach," were often pronounced as "bark," "bin," "back," and "beach."

The problem with phoneme /v/ is very similar to that of /p/. In Arabic this phoneme is absent, but its voiceless counterpart /f/ exists (Table B, p.56). The "v" sound will sometimes occur in loan words, but again, there will be the strong tendency to substitute "f" for " $v$." Therefore, it may take some time for learners of English to overcome this tendency. Words such as "vine," "veil," "vary," and "live" will often be misinterpreted for "fine," "fail," "fairy," and "life". However, /v/ does not seem to be a big problem for the participants in this study. Half of the participants of this study experienced problems with the 
phoneme /V/; they are participants C, D, and E. Participants in studies conducted by Tushyeh (1996), Altaha (1995), Avery and Ehrlich (1992), Kharma \& Hajjaj (1989), also had difficulties in pronouncing this phoneme.

The other consonant sounds mispronounced by the Arabic speakers of this study are consonants present in the Arabic phonetic inventory. However, they have a different phonetic realization. According to Kharma and Hajjaj (1989), although the sounds " $n$ " and " $\mathrm{"} \mathrm{exist} \mathrm{in} \mathrm{Arabic,} \mathrm{they} \mathrm{are}$ both allophones of the same phoneme /n/. In English, on the other hand, /n/ and /y/ are distinct phonemes differentiated by minimal pairs such as sin/sing. The velar nasal /y/ never occurs at the end of a word in Arabic, but only occurs before a velar stop. This may explain why all of the participants added the sound /k/ at the end of words finishing with /y/. For example: mispronouncing "buying" [bayı], for [bayınk] .

Another sound that represented a major problem for almost all of the participants of this study was the "l" sound. According to an article published by the Australian Government (1978), in Arabic this sound has two allophones: the plain "l" [1], and the velarized "l" [ł]. In American English there is only the dark "l" / / / which is used in 
every position. In Arabic, the velarized "l" only occurs before a following emphatic (emphatic consonants refer to a set of obstruents with a secondary articulation usually velarization, pharyngealization or glottalization). As in English there are no "emphatics," Arabic speakers will have the strong tendency to use the plain [1] for every occurrence of the phoneme /l/. Therefore, the pronunciation of these words will often sound foreign.

The phoneme /d/ is present in English and in Arabic. However, its manner of articulation is different. In English the consonant " $d$ " at the end of words is often unreleased but retains its voicing. In Arabic the " $d$ " is always released in word final position, and it is voiceless in this position. This allophonic difference may cause the native speakers of Arabic to mispronounce the " $d$ " sound as a " $t$ " sound. This way, words such as "bed," "cod," "rod," "mad," will often be pronounced as "bet," "cot," "rot," and "mat" by native speakers of Arabic. The results of this study show that every participant, at some point, experienced difficulties in the pronunciation of this consonant at word final position.

Another phoneme which is present both in Arabic and English is the phoneme /r/. However, Kharma \& Hajjaj (1989) note that the Arabic /r/ is an alveolar trill, whereas the 
English /r/ is a frictionless retroflex continuant. The English sound of / $r /$, which is often phonetically represented /L/, is not familiar to the Arabic speakers and they will have the strong tendency to produce this sound the way they know it in Arabic. This mispronunciation may not cause misinterpretation by the English native speakers, however it will strongly contribute to the foreign accent. Looking carefully at our findings, we can see that problems with consonant sounds /d / and /ð/ were experienced only by participants $A$ and $B$. The aspect that these two participants have in common is their nationality. They are the only two participants from Egypt included in this research study.

We have to take into account, that although all the participants of this study speak the same language (Arabic), there are colloquial dialects, which differ from classic Arabic and from one region to another, and are used in everyday conversation. Consequently, Arabic speakers from different countries may have different problems in English pronunciation.

According to Kharma \& Hajjaj (1989), difficulties with the consonant sounds /dz/ and /o/ are typical problems of the Egyptian Arabic. In standard classical Arabic the consonant 
sound /d / exists and is used, whereas in some modern spoken varieties, including that of Egypt, /3/ is substituted for /db/. This way, words such as "job" and "jam" would respectively sound like [3ab] and [3æm], in English and in the Egyptian variety of Arabic.

The other problem experienced only by participants A and $B$ was the consonant sound / $/$. This sound is common in the standard classical Arabic, and therefore, Arabic speakers should not encounter problems in producing them. However, in some modern spoken varieties of Arabic, such as that of Egypt, this sound is replaced by its plosive equivalent /d/. Consequently, words such as "their," "they," "then," and "though," would respectively sound like "dare," "day," "den," and "dough," in English and in the Egyptian variety of Arabic.

As expected, the percentage of errors in the pronunciation of consonant sounds /y/ and /d/ varied depending on their place of occurrence. For example: when saying "doing well" without a pause between the two words, a tendency of pronouncing the /y/ sound correctly according to the SAE was noticed. However, if they paused, "doing (pause) well," the mispronunciation for /gk/ was more likely to occur. The same is true for the consonant sound 
/d/. When saying, for example, "studied English" without a pause between the two words, the right pronunciation of the /d/ was more likely to occur. The pronunciation of these words with pause, "studied (pause) English," would lead to a higher percentage of mispronunciation having the /d/ sound devoiced and becoming a /t/ sound. As mentioned before, these two sounds exist in the Arabic language, however, their distribution may differ from that of English language consonants. Although the consonant sound [y] exists in the Arabic language, it never occurs in a word final position (Kharma and Hajjaj, 1989). This way, when the word "doing" is linked to the next one, it will sound as if [y] is not in the final position, and therefore, the sound will often be pronounced correctly by the Arabic native speakers. The same seems to be true for the /d/ sound. However, the phoneme /d/ has two allophones in the Arabic language. While in word final position the pronunciation of this consonant is devoiced, differing from the English pronunciation, at word initial or medial positions it is produced the same way it is in English. Therefore, the nonnative pronunciation will appear only at phrase final position. Another factor to be taken into consideration, before the closure of this chapter, is the spelling difference 
between the two languages. Although not discussed in this study, this difference can also account for the causes of errors produced by Arabic speakers learning English. As the Australian Publishing Service (1978) establishes:

The influence of the Arabic writing system is likely to affect reading, spelling, handwriting and pronunciation. Arabs will probably tend to expect the spelling to represent the pronunciation more consistently than it does, and thus to pronounce silent consonants, etc. (Australian Government Publishing Service, 1978. $\mathrm{p} .2)$

Kharma \& Hajjaj (1989), agree with the previous statement. They believe that the irregularity of the English spelling often leads to mispronunciation. Arabic speakers are misled by the graphic representation of sounds in English, whereas in Arabic the spelling is extremely regular. The following chapter will provide the conclusions of this research. 


\section{Chapter 6}

Conclusions

This research study demonstrated that Arabic speakers who were immersed in an English-speaking country after the age of puberty experienced difficulties in pronouncing certain English consonant sounds. To date, there is very little research investigating the pronunciation problems encountered by Arabic speakers when learning English (Tushyeh, 1996; Altaha, 1995; Avery and Ehrlich, 1992; Kharma and Hajjaj, 1989). Moreover, the research that exists in this area investigates Arabic speakers who never left their country in order to learn English, or who just arrived in the target language country. There is no research investigating the persistent difficulties Arabic speakers face even after being immersed in the target language culture for a significant period of time.

The participants of this study were subjected to an interview, sentences reading, and minimal pairs reading, where some of the difficulties in the consonant inventory were clearly manifested through mispronunciation of the words. The mispronunciation of certain consonant phonemes may lead to the presence of a foreign accent or even to 
misinterpretation of meaning by native speakers of English, thus it is important to find the major cause of the difficulties.

Interference from the mother tongue seems to be the major factor contributing to pronunciation problems. Most of the problematic consonants identified in this study were also identified in studies conducted by Tushyeh (1996), Altaha (1995), Avery and Ehrlich (1992), Kharma \& Hajjaj (1989). However, as their participants had not lived in the target language culture for a significant period of time, they also had problems with other consonant sounds not mentioned in this study. Four out of eight problematic consonant sounds identified in this study are present in the Standard Arabic Phonetic System. They are: /y/ in phrase final position as in "buying" [bayı], /t/ as in "civil" [sivit], /d/ in word final position as in "bed" [bed], /r/ (/ð/) as in "risk" [むIsk]. However, although these consonant segments are present in both languages, their phonetic realization is different. The incorrect articulation of these phonemes is not likely to cause miscommunication with native speakers of English (with exception of /y/ and /d/ sounds which may cause 
miscommunication), but they will result in a foreign accent.

Two out of eight consonants identified to be of problematic pronunciation to the Arabic speakers of this study are not present in the Standard Arabic phonetic system. They are: /p/ as in "play" [pley] and /v/ as in "five" [fayv]. However, their counterparts, which are /b/ and /f/, are present in the phonetic system and, therefore, Arabic speakers will have the strong tendency of substituting the voiced bilabial /b/ for the voiceless /p/, and the voiceless /f/ for the voiced /v/, which are the nearest sounds to the English ones. The incorrect pronunciation of these two consonant sounds are very likely to produce a foreign accent and may lead to misinterpretation of meaning by the native speakers of English, as illustrated in the anecdote at the beginning of the "discussion" chapter (p.49). Another factor that needs to be taken into consideration is that although all participants of this study speak the same language (Arabic), they are from different countries, and therefore are speakers of different regional varieties of Arabic. Consequently, Arabic speakers from different areas may have different problems with English, especially pronunciation. Regarding 
this study, the participants from Egypt were the only ones who experienced problems pronouncing the consonant segments /d3/ and /ð/, since in the Egyptian modern spoken variety of Arabic these sounds were replaced by /3/ and /d/, respectively. Therefore, words such as "job" [dzab] and "the" [ðə] are often mispronounced as respectively [3ab] and [də] . The incorrect pronunciation of the /dy/ sound is not likely to cause miscommunication with native speakers of English, but it will be perceived as a foreign accent. The mispronunciation of the /ð/ sound is likely to cause miscommunication and may represent a foreign accent.

\subsection{Implications}

Attaining a native-like pronunciation after the age of puberty seems to be very difficult. However, with appropriate training this goal may be reached. This research study pointed out pronunciation difficulties with consonant sounds experienced by post pubertal Arabic speakers when learning English.

As was previously shown, there are certain differences involving the Arabic language, depending on the variety spoken. ESL teachers should be aware of those differences 
in order to teach English to Arabic speakers from different nationalities.

The results of this study may provide insights to ESL teachers for the development and choice of instructional methodology, which may improve the teaching of pronunciation of English to Arabic speakers who are interested in improving their pronunciation skills to the point of losing their foreign accent.

\subsection{Limitations of the study}

This research study was limited to the pronunciation of English consonant phonemes such as /p/, /p/, /v/, /d/, / $/ /, / d \xi /, / \partial /$, and / I/, which were identified as problematic for Arabic speakers.

The results from this study may be different from studies in which Arabic speakers from other nationalities were being investigated, since the modern spoken variety of Arabic may differ from country to country.

The subjects investigated in this study were aware of the purpose of the research and that they were being tape recorded in order to find mispronunciations in their speech. Therefore, they may have been self-conscious about their pronunciation, and produced less natural speech. 
Thus, the data collected may not exactly represent the participants everyday speech.

\subsection{Suggestions for Further Research}

An investigation of the difficulties experienced by post puberty Arabic speakers immersed in an English language speaking country in pronouncing English vowels segments would be considered relevant to this study. In order to minimize the accent in a foreign language, not only should problematic consonants be identified, but also the vowels and stress patterns. Therefore, another complementary study would involve identifying and analyzing the stress patterns in Arabic speakers' English speech. Concerning the instructional strategies to be used in order to minimize or eliminate the presence of a foreign accent, research is also suggested, so that good techniques can be available to ESL teachers.

Considering the fact that this research study only included six participants, further research is suggested involving a larger number of subjects.

There is no literature available which explains the devoicing of the /d/ at phrase final position by Arabic speakers learning English. Therefore, research in this area is strongly recommended. 
An investigation about the influence of the spelling in pronunciation acquisition would be considered complementary to this study, since there has been no focus on this area. 


\section{Works Cited}

Ali, M. (1995). A case grammar and style complexity approach: A stepping-stone from error analysis towards writing pedagogy. Dissertation abstracts international, 55, 3490-3491.

Altaha, F. (1995). Pronunciation errors made by Saudi university students learning English: analysis and remedy. ITL: Review of applied linguistics, 109, $110-123$.

Arabski, J. (1984). The role of age in second/foreign language acquisition. International journal of applied linguistics, 17, 65-71.

Asher, J., \& Garcia, R. (1969). The optimal age to learn a second language. In Krashen, S., Scarcella, R., \& Long, M. (Eds.), Child-adult differences in second language acquisition (pp.3-12). Newbury House Publishers, Inc. Rowley, Massachusetts. Australian Government (1978). English a new language: likely difficulties of English pronunciation for Arabic speakers (pp. 1-43).

Avery, P., \& Ehrlich, S. (1992). Teaching American English Pronunciation. Oxford University Press. 
Bialystok, E. (1997). The structure of age: in search of barriers to second language acquisition. Second language research, 13, 116-137.

Bongaerts, T., Planken, B. (1997). Age and ultimate attainment in the pronunciation of a foreign language. Studies in second language acquisition, 19, 447-65.

Broselow, E. (1988). An investigation of transfer in second language phonology. Interlanguage studies, 77-93.

Collier, V. (1987). Age and rate of acquisition of second language for academics purposes. Tesol quarterly, $28,617-641$.

Cook, V. (1983). Child adult differences in second language acquisition. Journal of the international linguistic association, 34, 122-129.

Diab, N. (1996). The transfer of Arabic in the English writings of Lebanese Students. The ESP, 18, 71-82.

Fakhri, A. (1994). Text organization and transfer: The case of Arab ESL learners. International review of applied linguistics in language teaching, 32, 78-86. Fromkin, V., Krashen, S., Curtiss, S., Rigler, D., \& Rigler, M. (1998). The development of language in Genie: a case of language acquisition beyond the "critical period". Language: readings in language and culture, 589-603. 
Ioup, G., Tigi, M., \& Boustagui, E. (1994). Reexamining the critical period hypothesis: a case study of successful adult SLA in a naturalistic environment. Studies in second language acquisition, 16, 73-98.

Juffs, A., \& Harrington, M. (1995). Parsing effects in L2 sentence processing: subject and object asymmetries in wh-extraction. Studies in second language acquisition, 17, 483-516.

Kallkvist, M. (1995). A review of recent research on age related differences in second language acquisition. Research center for English and applied linguistics, $1,155-158$.

Kharma, N., \&Hajjaj, A. (1989). The sound system. Errors in english among Arabic speakers (pp.11-19). Alfred Place, London.

Krashen, S., Long, M. \& Scarcella, R. (1978). Age, rate and eventual attainment in second language acquisition. Tesol quarterly, 13, 161-172.

Krashen, S. (1981). Accounting for child-adult differences in second language rate and attainment. In Krashen, S., Scarcella, R., \& Long, M. (Eds.), Child-adult differences in second language acquisition (pp.202225). Newbury House Publishers, Inc. Rowley, Massachusetts. 
Lenneberg, E. (1967) . Biological foundations of language. Wiley, New York.

Marzouk, G. (1993). Some aspects of phonological transfer from Arabic to English. Journal of the Irish association for applied linguistics, 13, 29-40. McDonald, J. (2000). Grammatically judgments in a second language: influences of age of acquisition and native language. Applied psycholinguistics, 21, 395-423.

McLaughlin, B. (1984). Second-language acquisition in childhood. Annual review of applied linguistics, 10, $122-134$

Mayo, L. (1997). Age of second-language acquisition and perception of speech in noise. Journal of speech, language, and hearing research, 40, 686-693.

Meziani, A. (1984). Maroccan learner's English errors: a pilot study. International review of applied Linguistics in Language Teaching, 22, 297-310.

Murcia, M., Brinton, D., \& Goodwin, J. (1996). Teaching Pronunciation. Cambridge University Press. Mukattash, L. (1981). Problems in error analysis. Papers and studies in contrastive analysis, 13, 261-274. Nilsen, D., \& Nilsen, A. (1973). Pronunciation contrasts in English. New York, NY.

Oyama, S. (1976). A sensitive period for the acquisition of 
a nonnative phonological system. In Krashen, S., Scarcella, R., \& Long, M. (Eds.), Child-adult differences in second language acquisition (pp.20-37). Newbury House Publishers, Inc. Rowley, Massachusetts. Oyama, S. (1976). A sensitive period and comprehension of speech. In Krashen, S., Scarcella, R., \& Long, M. (Eds.), Child-adult differences in second language acquisition (pp.39-51). Newbury House Publishers, Inc. Rowley, Massachusetts.

Penfield, W., Roberts, L. (1959). Speech and brain mechanisms. Princeton University Press, Princeton, NJ. Radwan, A. (1988). A linguistic analysis of the grammatical and lexical errors in the nominal group found in the written English of Syrian university students. Dissertation abstracts international, 49, 1392.

Samuels, J., \$ Olson, L. (1972). The relationship between age and accuracy of foreign language pronunciation. In Krashen, S., Scarcella, R., \& Long, M. (Eds.), ChildAdult Differences in Second Language Acquisition (pp.67-75). Newbury House Publishers, Inc. Rowley, Massachusetts.

Sayed, M. (1983). An investigation into the syntactic errors of Saudi freshmen's English compositions. Dissertation abstracts international, 43, 3306 
Scovel, T. (1981). The recognition of foreign accents in English and its implications for psycholinguistic theories of language acquisition. In Savard, J. \& Laforge, L. (Eds.), Proceedings of the $5^{\text {th }}$ congress of l'association internationale de linguistique appliqueé (pp. 389-401). Les Presses de L' Université Laval, Québec .

Seliger, H., Krashen, s., \& Ladefoged, P. (1978). Maturational constraints in the acquisition of a second language. Language sciences, 36, 20-22.

Semmander, R. (1987). A comparison of spoken with written texts with respect to error and non-error cohesive ties and syntactic structures of adult Arabicspeaking learners of English as a foreign language. Dissertation abstracts international, 48, 1138.

Shaheen, A. (1984). Errors and the teaching of literature. International review of applied linguistics in language teaching, 22, 311-316.

Singleton, D. \& Lengyel, Z. (1995). The age factor in second language acquisition. Multilingual Matters, Clevedon, UK ; Philadelphia.

Snow, C. (1979). Age differences in second language acquisition: research findings and folk psychology. Second language acquisition studies, 141-150. 
Snow, C., \& Hohle, M. (1978). Age differences in the pronunciation of foreign sounds. In Krashen, S., Scarcella, R., \& Long, M. (Eds.), Child-adult differences in second language acquisition (pp.84-92). Newbury House Publishers, Inc. Rowley, Massachusetts.

Snow, C., \& Hohle, M. (1979). The critical period for language acquisition: evidence from second language learning. In Krashen, S., Scarcella, R., \& Long, M. (Eds.), Child-adult differences in second language acquisition (pp.93-110). Newbury House Publishers, Inc. Rowley, Massachusetts.

Tahta, S., Wood, M., \& Loewenthal, K. (1981). Foreign accents: factors relating to transfer of accent from the first language to a second language. Language and speech, 24, 265-272.

Thompson, I. (1991). Foreign accents revised: the English pronunciation of Russian immigrants. Language learning, 41, 177-204.

Tushyeh, H. (1996). Linguistic problems facing Arab learners of English. ITL: Review of applied linguistics, 111, 109-117.

Towell, R., Hawkins, R. (1992). Second language acquisition research and the second language acquisition of French. Journal of French language studies, 2, 97-121. 
White, L. (1998). Second language acquisition and binding principle B: child/adult differences. Second language research, 14, 425-439.

Walsh, T., \& Diller, K. (1991). Neurolinguistics

considerations on the optimum age for second language learning. In Diller, K. (ed.), Individual differences and universals in language learning aptitude (pp.321). Rowley, MA.

Wode, H. (1991). Nature, nature, and age in language acquisition: the case of speech perception. Studies in second language acquisition, 16, 325-345. 


\section{Appendix 1}

Demographic Questionnaire

Male Female

1) How old are you?

18-23_ 24-29_ 30-35_ over 35_

2) What country are you from?

3) What is your native language?

4) What is your level of education? Graduate Undergraduate Other (specify)

5) What do you do in the US?

6) How long have you lived in the US? (Total of years including states other than West Virginia).

Less than 5 years $5-6$ years

$7-8$ years over 8 years

7) a) How long have you studied English in your country before coming to the US?

$$
\begin{aligned}
& \text { Less than } 1 \text { year__ 1-2 years___ 3-4 years__ 5- } \\
& 6 \text { years } \\
& \text { 7-8 years_over } 8 \text { years }
\end{aligned}
$$

8) Any other experience abroad in an English speaking country?

9) How often do you interact with English native speakers?

I rarely interact with native speakers 
only once a week

2 to 4 days a week

7 days a week, few hours per day

7 days a week, many hours per day

10) Are your close friends

all English native speakers?

mostly English native speakers?

mostly English non-native speakers?

all English non-native speakers?

11) To what extent are you motivated to improve your English?

Very motivated somewhat motivated

not motivated at all

12) What do you do in order to improve your English?

Listen to the radio

Watch TV

Talk to Americans

Read books

Other what?

13) What other experiences or factors influenced your skills in English? 


\section{Appendix 2}

\section{Sentences:}

1. Chicken flavored pie is my favorite recipe.

2. Practicing sports helps keeping the parts of the body fit.

3. Bill rang the bell and took the pill at five o'clock.

4. There are many robes and ropes on the pet's bed.

5. Reading is my favorite activity.

6. What are you doing in the morning?

7. Those three deer saw the thief escaping.

Minimal pairs:

1. Pie bye

2. Pet bet

3. Pride bride

4. Mopping mobbing

5. Cop cob

6. Rope robe

7. Leave leaf 